\title{
ARTICLES
}

\section{ENSURING ADEQUATE HEALTH CARE FOR THE SICK: THE CHALLENGE OF THE ACQUIRED IMMUNODEFICIENCY SYNDROME AS AN OCCUPATIONAL DISEASE}

\author{
Troyen A. BrenNAN*
}

The acquired immunodeficiency syndrome (AIDS) is having an unprecedented impact on the American health care system. The disease itself is a biological phenomenon in that it strikes young and previously healthy people, cripples their immune system, and leads to their death within two to three years. ${ }^{1}$ Even more disturbing, the syndrome was unrecognized only seven years ago. As a result, we have hittle experience with fighting the human immunodeficiency virus (HIV), which is the etiological agent for AIDS, and the prospects of potent therapy or a useful vaccine are still quite dim. ${ }^{2}$ Fortunately, however, we have made great

* Instructor, Harvard Medical School; Lecturer, Harvard Law School; Research and Teaching Scholar, American College of Physicians. The author is indebted to Tanya Scott, Harvard Law School, Class of 1989, for her ideas and research assistance; to Paul Weiler for his thoughtful criticism; and for the discussions with colleagues at a meeting of the Harvard University AIDS Task Force and a seminar at the Umiversity of Washington Law School.

1. AIDS is defined by a series of diseases associated with immune compromise as well as by infection with Human Iminunodeficiency Virus (HIV). Centers for Disease Control, Revision of the Case Definition of Acquired Immunodeficiency Syndrome for National Reporting-United States, 34 MORBIDITY \& MORTALITY WEEKLY REP. 373, 373-74 (1985). One cominentator projected that by March of 1987, 32,000 cases would have been reported. Mueller, The Epidemiology of the Human Immunodeficiency Virus Infection, 14 LAW MED. \& HEALTH CARE 250, 250 (1986). The disease in this country oceurs largely in certain risk groups, including homosexual males, Haitian mimigrants, intravenous drug abusers and hemophitiacs. Goedert \& Blattner, The Epidemiology of AIDS and Related Conditions, in AIDS: ETIology, Diagnosis, TREatMent, and Prevention 1, 16-20 (V. Devita, S. Hellman \& S. Rosenberg eds. 1985). Transmission follows this pattern because the virus can be spread only through contact with contaminated blood or body fluids. Id. at 21-22.

2. Certain pharmacological agents appear to be able to decrease the rate of developinent of the opportunistic infections associated with AIDS. Certainly there are no claims of cures with these agents.

Vaccine developmeut has been delayed by the biological complexity of the virus. See, e.g., Hahn, Genomic Diversity of the Acquired Immune Deficiency Syndrome Virus HTLV-III: Different Viruses Exhibit Greatest Divergence in their Envelope Genes, 82 PROC. NAT'L ACAD. SCI. USA 481317 (1985) (noting that if differences in nucleic acid sequences of HTLV-III viruses affect the anti- 
strides in that in such a short time we have identified the virus ${ }^{3}$ and the nature of its transinission, ${ }^{4}$ and have developed excellent and relatively cheap tests for screeining for its presence. ${ }^{5}$

Given this information, we now have the ineans to wage a public liealth war against the spread of the HIV. Inevitably, however, a public lealth war must involve the exercise of the pohce power of the state, and in a society like ours that values personal hiberty, ${ }^{6}$ this means that hard decisions have to be inade. It is no surprise, then, that the AIDS epidemic has forced us to rethink many of the doctrimes that underlie public health protection ${ }^{7}$ and has raised a daunting array of legal questions. ${ }^{8}$ Many inore difficult questions are on the horizon, especially questions

genic properties of the viruses, development of effective vaccine will be complicated). As Wendy Mariner and Robert Gallo note: "The research community has a relatively clear picture of possible approaches to developing vaccines and of the steps required to identify which, if any, of these can be successful. This does not mean that the task is simple or that it will result in an effective vaccime." Mariner \& Gallo, Getting to Market: The Scientific and Legal Climate for Developing an AIDS Vaccine, 15 LAw MED. \& Health CARE 17, 19 (1987).

3. The HIV was almost simultaneously discovered by two groups, one in the United States that called the virus "human T-lymphotropic retrovirus" (HTLV-III), Gallo, Salahuddin, Popovic, Shearer, Kaplan, Haynes, Palker, Redfield, Oleske, Safai, White, Foster \& Markham, Frequent Detection and Isolation of Cytopathic Retroviruses (HTLV-III) from Patients with AIDS and at Risk for $A I D S, 224$ SCIENCE 500-03 (1984); and another in France that called the virus "lymphadenopathyassociated virus” (LAV), Barré-Sinoussi, Mathur-Wagh, Rey, Brun-Vezinet, Yancovitz, Rouzioux, Montagnier, Mildvan \& Chermann, Isolation of Lymphadenopathy-Associated Virus (LAV) and Detection of LAV Antibodies from US Patients with AIDS, 253 J. A.M.A. 1737 (1985). The term human immunodeficiency virus was adopted by agreement. See Gallo \& Montagnier, The Chronology of AIDS Research, 326 NATURE 435 (1987).

4. See Goedert \& Blattner, supra note 1, at 16-22; Mueller, supra note 1, at 256.

5. See Screening for AIDS, 27 MED. LETTER 29-30 (1985); Council on Scientific Affairs, Division of Scientific Activities, American Medical Association, Status Report on the Acquired Immunodeficiency Syndrome, 254 J. A.M.A. 1342-54 (1985).

6. See generally R. Nozick, ANarchy, State, ANd Utopia (1974); J. Rawls, A Theory OF JUSTICE (1971).

7. Curran, Clark \& Gostin, AIDS: Legal and Policy Implications of the Application of Traditional Disease Control Measures, 15 LAw MED. \& HEALTH CARE 27-33 (1987) (traditional disease control measures restricting personal freedom are incousistent with individual rights and are more of a response to public fears than public health reality).

8. The legal issues that have arisen in the past three years include: the rights of children with AIDS to attend school, see District 27 Community School Bd. v. Board of Educ., 130 Misc. 2d 398, 502 N.Y.S.2d 325 (Sup. Ct. 1986); AIDS as a souree of discrimination in the workplaee, see Shuttleworth v. Broward County, 2 Empl. Prac. Guide (CCH) If 5014 (Fla. Comm'n of Human Relations 1985); see also Shuttleworth v. Broward County, 639 F. Supp. 654 (S.D. Fla. 1986) (discussion of employee's federal and state constitutional claims as well as federal statutory claims against Broward County); the segregation of prisoners with AIDS froin the general inmate population, see Cordero $v$. Coughlin, 607 F. Supp. 9 (S.D.N.Y. 1984); preventimg imsurance rate-setting on the basis of HIV seropositivity, see American Council of Life Ins. v. District of Columbia, 645 F. Supp. 84 (D.D.C. 1986); municipal authority closing establishments associated with unsafe medical practices, see City of New York v. New St. Mark's Baths, 130 Misc. 2d 911 , 497 N.Y.S.2d 979 (Sup. Ct.), aff'd mem., 122 A.D.2d 747, 505 N.Y.S.2d 1015 (1986), appeal dismissed, 70 N.Y.2d 693, 512 N.E.2d 555 (1987); and the tort hability of people vho knowingly transmit the HIV, see Baruch, AIDS in the 
concerning quarantine and antidiscrimination law. ${ }^{9}$ Commentators also have voiced concerns about legal liability for health care professionals. ${ }^{10}$

Most liealth care practitioners are more concerned with the biological hazards than they are with the legal hazards of caring for victims of AIDS. ${ }^{11}$ Yet the HIV appears to have a very low transmission rate during casual contact, ${ }^{12}$ and lealth care workers have been thought to be protected as long as they observe precautions when dealing with blood and other body fluids. ${ }^{13}$ In the summer of 1987 , however, the Centers for

Courts: Tort Liability for the Sexual Transmission of Acquired Immune Deficiency Syndrome, 2 TORT \& INS. L.J. 165 (1987).

The state legislatures have been very active on the AIDS issue. See Lewis, Acquired Immunodeficiency Syndrome: State Legislative Activity, 258 J. A.M.A. 2410 (1987). States have enacted laws on the reporting of positive results, confidentiality of testing, enployment, informed consent and insurance. Id.; see also Oloroso \& Cristan, States Swamped with AIDS Bills, Am. Med. News, June 26,1987 , at 1 .

9. The Supreine Court's decision in School Bd. v. Arline, 107 S. Ct. 1123, 1132 (1987) (person suffering from contagious disease of tuberculosis considered handicapped within ineaning of Rehabilitation Act of 1973), has led to a great deal of conjecture about the treatment of AIDS as a handicap under section 504 of the Rehabilitation Act of 1973, 29 U.S.C.A. $\$ 794$ (West Supp. 1988). See e.g., Parmet, AIDS and the Limits of Discrimination Law, 15 LAW MED. \& HEALTH CARE 61 (1987) (reviewing Arline and other aspects of discrimination law and finding them inadequate). There is hittle doubt that any quarantine law would have to be very carefully constructed to survive scrutiny for discriminatory intent. See generally Parmet, AIDS and Quarantine: The Revival of an Archaic Doctrine, 14 HOFSTRA L. REv. 53 (1985) (examining the law of quarantine and its implications in light of the AIDS epidemic).

10. See, e.g., Hermann, Liability Related to the Diagnosis and Transmission of AIDS, 15 LAW MED. \& HEALTH CARE 36, 36-39 (1987) (discussing AIDS-related medical malpractice actions). Foremost among these concerns is the fcar that physicians may be held responsible for failing to give Tarasoff-style warnings to sexual partners of AIDS victims. See Tarasoff v. Regents of the University of Cal., 17 Cal. 3d 425, 434-35, 551 P.2d 334, 342, 131 Cal. Rptr. 14, 22 (1976).

11. See Banks, The Right to Medical Treatment, in AIDS AND THE LAW: A GUIDE FOR THE Public 175, 175 \& n.1 (H. Dalton \& H. Burris eds. 1987) (citing AIDS Risk Troubles MDs, Dr. Volberding Reports, Am. Med. News, Oct. 18, 1985, at 3); see also Volberding \& Abrams, Clinical Care and Research in AIDS, 15 HASTINGS CENTER REP., Aug. 1985 Special Supp., at 16 (discussing problein of personal risk to physicians treating AIDS patients); Staver, Delegates File Report on AIDS Ethical Issues, Am. Med. News, Dec. 18, 1987, at 31.

12. See Friedland, Saltzman, Rogers, Kahl, Lesser, Mayers \& Klein, Lack of Transmission of HTLV-III/LAV Infection to Household Contacts of Patients with AIDS or AIDS-Related Complex with Oral Candidiasis, 314 NEw ENG. J. MED. 344 (1986) (concluding that "household contacts who are not sexual partners of, or born to, patients with AIDS are at ininimal or no risk of infection with HTLV-III/LAV"); Jason, McDougal, Dixon, Lawrence, Kennedy, Hilgartner, Aledort \& Evatt, HTLV-III/LAV Antibody and Immune Status of Household Contacts and Sexual Partners of Persons with Hemophilia, 255 J. A.M.A. 212 (1986).

13. See Henderson, Saah, Zak, Kaslow, Lane, Folks, Blackwelder, Schmitt, LaCamera, Masur \& Fauci, Risk of Nosocomial Infection with Human T-Cell Lymphotropic Virus Type III/Lymphadenopathy-Associated Virus in a Large Cohort of Intensively Exposed Health Care Workers, 104 ANNALS INTERNAL MED. 644 (1986); Lifson, Castro, McCray \& Jaffe, National Surveillance of AIDS in Health Care Workers, 256 J. A.M.A. 3231 (1986). The precautions that health care workers would employ involve the use of gloves when handling any blood or other body fluids such as sputum, urine or any discharges, as well as the use of masks and special clothing when aerolisation of blood or body fluids is expected. Update: Human Immunodeficiency Virus Infections in Health Care Workers Ex- 
Disease Control (CDC) reported three cases of HIV infection in health care workers who had been exposed to HIV seropositive blood in fashions previously thought to be rather trivial. ${ }^{14}$ In addition, other researchers demonstrated that the HIV infection rate was much higher in people admitted to einergency rooms ${ }^{15}$ and in military recruits. ${ }^{16}$ Thus the assumption that occupational transmission of HIV could only occur after a needlestick injury involving a nember of a recognized high risk group was questioned.

At much the same time, a physician filed the first occupationally related AIDS suit against a hospital, claiming that he developed AIDS after he was exposed to HIV by a blood tube accident. ${ }^{17}$ This suit has heightened health care workers' awareness of the dangers of HIV as an occupational disease and has led to the quiet institution of mandatory

posed to Blood of Infected Patients, 36 MORBIDITY \& MORTALITY WEEKLY REP. 285, 288 (1987) [hereinafter Update].

14. Update, supra note 13, at 285-89. Most health care workers were aware that the HIV could be spread in a hospital if percutaneous exposure occurred. The overwhelming majority of percutaneous exposures to serum in a hospital are caused by accidental needlesticks. Before this report, several cases of HIV infection were known to have followed needlesticks. Id.

This particular report was disturbing because none of the cases involved needlesticks. The exposures in these cases involved the splashing of blood on health care workers' skin or in their eyes. Id. Given the ubiquity of these kinds of exposure in an acute care hospital, this report was especially widely read and discussed amoug health care workers. See Brennan, The Acquired Immunodeficiency Syndrome (AIDS) as an Occupational Disease, 107 ANNALS INTERNAL MED. 581, 581 (1987).

15. See Baker, Kelen, Sivertson \& Quinn, Unsuspected Human Immunodeficiency Virus in Critically Ill Emergency Patients, 257 J. A.M.A. 2609, 2609-11 (1987) (6 of 203 critically or severely injured patients with no history of HIV infection tested seropositive for HIV antibody).

16. See Burke, Brundage, Herbold, Berner, Gardner, Gunzenhauser, Voskovitch \& Redfield, Human Immunodeficiency Virus Infections Among Civilian Applicants for Uniled States Military Service, October 1985 to March 1986: Demographic Factors Associated with Seropositivity, 317 NEw ENG. J. MED. 131, 131-36 (1987) (study showing results of large-scale HIV test given to military recruits). It has been very difficult to determine the rate of HIV seropositivity in low-risk populations. Military recrnits, people admitted to emergency rooms, and people who go to anonymous testing centers may be at a proportionately higher risk than a random sample of the population. One way to define prevalence may be to use blood samples from newborns in a manner such that the newborn cannot be identified but the blood can be tested for HIV. For an example of testing newborns to determine HIV prevalence among childbearing women, see Landesman, Minkoff, Holman, McCalla \& Sijin, Serosurvey of Human Immunodeficiency Virus Infection in Parturients, 258 J. A.M.A. 2701 (1987). The key to any survey that allows one to estimate prevalence is to sample without the need for consent and to ensure strict confidentiality of results. For an example of how these parameters apply to pregnant women, see Minkoff, Care of Pregnant Women Infected with Human Immunodeficiency Virus, 258 J. A.M.A. 2714 (1987).

17. Barker, Physician Sues Johns Hopkins After Contracting AIDS, Am. Med. News, June 19, 1987, at 30. The suit sounded in tort and alleged a breach of confidentiality by the hospital. See Brennan, supra note 14, at 582. Numerous anecdotal reports about this case have been published, but to the best of my knowledge a trial date still has not been set. 
screening of all patients by soine hospitals. ${ }^{18}$ We now hear conflicting opinions about the risk of occupationally induced AIDS; this is best exemplified by the situation in which the researchers at San Francisco General Hospital announced that the occupational risk of contracting HIV is quite low, ${ }^{19}$ while at the same tinie, the chief of orthopedics at the same hospital announced a new policy of requesting all patients who are awaiting elective surgery to undergo testing for HIV.20 Thus it appears that health care workers' (especially doctors') perceptions of the risk of AIDS as an occupational disease are changing. Indeed, some are now questioning whether the use of gloves offers definite protection. ${ }^{21}$

Current evidence indicates that there is a small but definite risk of infection with HIV for health care workers caring for HIV seropositive patients. Moreover, the risk of death froin AIDS over a ten-year period

18. At least one major medical center is planning to require that all patients who plan to undergo invasive procedures be tested for HIV. See AIDS News, HEALTH L. NEwS REP., Dec. 1987, at 6, 7-8 (Methodist Hospital, Houston, Texas). Others have no doubt instituted such policies without much publicity. The Arizona State Board of Medical Examiners has apparently condoned such testing by stating that physicians have the right to refuse to treat AIDS patients. See Ariz MDs Can Refuse AIDS Patients, Am. Med. News, Nov. 6, 1987, at 37.

19. See Gerberding, Bryant-Leblanc, Nelson, Moss, Osmond, Chambers, Carlson, Drew, Levy \& Sande, Risk of Transmitting the Human Immunodeficiency Virus, Cytomegalovirus and Hepatitis $B$ Virus to Health Care Workers Exposed to Patients with AIDS and AIDS-Related Conditions, $156 \mathrm{~J}$. INFECTIOUS DISEASES 1, 1-8 (1987). These researchers conducted a prospective cohort study of 175 health workers over a 10-month period. Their exposure to AIDS patients was described as "intensive," but at the end of ten months, none of the workers had acquired the antibody to the HIV, indicating that none were infected with the virus. The researchers concluded that the risk for health care workers was minimal. Id. at 3-7.

While most would agree that the risk is "minimal," many would assert that aecidents do happen and the risk is real. At least one government employee who worked with the HIV in a research laboratory has contracted the HIV, even though he wore gloves and was careful. See Foreman, Lab Workers Warned on AIDS Danger, Boston Globe, Oct. 2, 1987, at 56. Morcover, mistakes can occur in the labeling of potentially hazardous laboratory specintens. See Handsfield, Cummings \& Swenson, Prevalence of Antibody to Human Immunodeficiency Virus and Hepatitis B Surface Antigen in Blood Samples Submitted to a Hospital Laboratory 258 J. A.M.A. 3395, 3396-97 (1987). Thus, while the best estimate of the risk of health care workers is that it is quite low, see Friedland \& Klein, Transmission of the Human Immunodeficiency Virus, 317 NEw ENG. J. MED. 1125, 1131-32 (1987), health care workers' perceptions of the risk will be greatly influenced by reports of cases of occupationally-related AIDS in which proper precautions were followed.

20. Orthopod Urges HIV Testing, Am. Med. News, Dec. 4, 1987, at 1. The surgeon, Dr. Lorraine Day, asked the other physicians doing orthopedic surgery to institute the same policy and also requested that they test themselves for HIV. She was quoted as saying:

I want people to face the fact that this is a new ethical problem for us. You can't just tell us, "You took the Hippocratic oath and you have to do this." It's just not that simple. Our lives are at risk. I want our health and safety to be part of the equation in deciding whether a patient gets the operation.

Id. She stated that the department would continue to do emergency surgery but could not define a bright-line difference between elective and emergency surgery. Moreover, she was not clear about those patients whose elective surgery was deferred. Since San Francisco General Hospital is a public hospital, its patients might not have alternative hospitals in which to seek surgery.

21. Lab Study Finds Infection Even with Wearing Gloves, AIDS Pol'y \& L., Jan 13, 1988, at 8. 
after one is infected is substantial-perhaps greater than $70 \%$. Thus while risk of infection is small, the consequences of infection are overwhelming. Health care occupations, whether they involve transporting patients or performing surgery, have long been perceived as low risk occupations. Presumably, those engaged in such occupations find the low risk associated with them appealing. It follows that the terrible consequences of a low risk hazard will have important repercussions in health care; the risks of HIV infection can create a sense of disquiet and prompt both rational and irrational methods to prevent such transmission.

In response, the $C D C$ has reissued its suggested precautions for handling blood specimens from AIDS patients, ${ }^{22}$ and the Occupational Safety and Health Administration (OSHA) has announced plans to release AIDS prevention regulations. ${ }^{23}$ The Joint Cominittee for the Accreditation of Hospitals plans to make such precautions mandatory for the hospitals it oversees. ${ }^{24}$ Despite these measures, if health care workers begin to perceive that HIV is transmitted even to those who take appropriate precautions, then it seems likely that both physicians and hospitals will take steps to limit exposures by limiting care.

What sort of steps are they likely to take? The first step-imsistence on screening for antibody to HIV-has already been taken by individual doctors and hospitals. ${ }^{25}$ As already noted with premarital screening, ${ }^{26}$ the relatively high false positive rate of the screening test alone will render such imitiatives quite problematic. ${ }^{27}$ The second step that hospi-

22. See infra text accompanying notes $122-24$. The $\mathrm{CDC}$ has also discussed in soine detail the risk of spreading HIV posed by an employee who is seropositive for HIV. See Summary-Recommendations for Preventing Transmission of Infection with Human T-Lymphotropic Virus Type III/ Lymphadenopathy-Associated Virus in the Workplace, 34 MoRBIDTTY \& MORTALITY WEEKLY REP. 681, 681-83 (1985); see also Health \& Pub. Pol'y Comm., Am. College of Physicians \& the Infectious Diseases Soc'y of Am., Position Paper: Acquired Immunodeficiency Syndrome, 104 ANNALS INTERNAL MED. 575, 575-76 (1985) ("The syndrome is a blood-borne, sexually transmitted disease that is not spread by occupational contact, even in the health care setting." (citations omitted)).

23. See Dep't of Labor \& Dep't of Health \& Human Servs., Joint Advisory Notice: Protection Against Occupational Exposure to Hepatitis B (HBV) and Human Immunodeficiency Virus (HIV), 52 Fed. Reg. 41,818 (1987) (issued Oct. 19, 1987).

24. Id.

25. See, e.g., supra notes 18,20 and accoinpanying text.

26. The screening test for HIV antibody is both inexpensive and relatively easy to complete and thus represents an important step forward in the effort to control the spread of the infection. However, the number of false positive results associated with the test, the low incidencc of seropositivity, and the fact that the impact of a false positive test is so devastating are factors that combine to overwhelm arguments in favor of mass screcning. See Cleary, Barry, Mayer, Brandt, Gostin \& Fineberg, Compulsory Premarital Screening for the Human Immunodeficiency Virus: Technical and Public Health Considerations, 258 J. A.M.A. 1757, 1759-62 (1987). The authors conclude that premarital screening would be quite expensive and would have little overall impact on infection rates.

27. See Barry, Cleary \& Fineberg, Screening for HIV Infection: Risks, Benefits, and the Burden of Proof, 14 LAW MED. \& Health Care 259, $264-66$ (1986) (concluding that the burden of proving 
tals and doctors are likely to take-limiting care for those whio are HIV seropositive-will be even more problematic.

Regardless of whether this limitation on care means that an elective case will be delayed or that HIV seropositive individuals will not be offered any care at all, any limitation of care based on one's disease status raises grave ethical and legal questions. In this article, I will focus on those questions and suggest soine policies that will help ensure that the threat of AIDS as an occupational disease does not limit access to care for HIV seropositive individuals. ${ }^{28}$

\section{Can Health Care Providers Refuse to Care for SEROPOSITIVE PATIENTS?}

\section{A. Legal Issues.}

The legal duties of individual physicians associated with the provision of care are quite different from those of hospitals. The paradigm for establishment of the doctor-patient relationship has long been one of contract. ${ }^{29}$ At common law, physicians have been allowed to refuse patients in noneinergency settings and to limit to certain kinds of problems or subspecialties the care they provide. ${ }^{30}$ Once a physician begms to treat a patient, however, a relationship is presumed and care must be continued until the patient no longer needs treatment for the specific problein, ${ }^{31}$ or the physician ends the relationship by giving the nonacutely ill patient adequate notice that would allow the patient to find a new physician. ${ }^{32}$

If a physician ends the doctor-patient relationship while the patient is still in need of care, the physician may be found to lave breaclied the

necessity of the test should be on those proposing the test); Bayer, Levine \& Wolf, HIV Antibody Screening: An Ethical Framework for Evaluating Proposed Programs, 256 J. A.M.A. 1768 (1986). These articles cogently outline the inanner in which the false positive rate of even a very accurate screening test for HIV is amplified in a low risk population.

28. In this article, I will emphasize the role of the physician, especially with respect to ethical questions. Because medicine is a hallmark profession, the question of ethical duties plays a special role in defining doctors' practices. The same is not true for a laboratory technician. The doctor is also held to ccrtain legal standards that other health care workers are not. See infra text accompanying notes 29-40. However, many of the legal issues discussed herem are applicable to a wide range of hospital employees. See infra text accompanying notes 40-69.

29. See McCoid, The Care Required of Medical Practitioners, 12 VAND. L. REv. 549 (1959) (arguing that the policy behind freedom to accept patients is that without the policy physicians could be inundated with patients, resulting in poor care for all (citing Hurley v. Eddingfield, 156 Ind. 416, 59 N.E. 1058 (1901))); see also Childs v. Weis, 440 S.W.2d 104 (Tex. Civ. App. 1969).

30. See A. Southwick, The Law of Hospital and Health Care Administration 97 (1978).

31. See, e.g., Hammonds v. Aetna Cas. \& Sur. Co., 237 F. Supp. 96, $98-99$ (N.D. Ohio 1965); Reed v. Laughlin, 332 Mo. 424, 430, 58 S.W.2d 440, 442 (1933).

32. See Payton v. Weaver, 131 Cal. App. 3d 38, 45, 182 Cal. Rptr. 225, 229 (1982); Saunders v. Lischkoff, 137 Fla. $826,836,188$ So. 815,819 (1939). 
implied contract, giving rise to actionable "abandonment." 33 The outlines of abandonment vary from court to court. In the leading case, the court held that failure to provide care constitutes abandonment when the patient needs notice of withdrawal and the initiated acute care must be continued. ${ }^{34}$ Physicians have been found hable for abandonment when they failed to provide follow-up care on a patient they had previously treated and who they knew liad not been cured, ${ }^{35}$ and when physicians delayed their attendance to patients they had reason to beheve were quite ill. ${ }^{36}$

Many of the cases outlining the parameters of abandonment are over thirty years old. More recently, the doctrine has been used to delineate the boundaries of consultation-particularly expert consultation. Under this analysis, a physician may incur a duty to treat a patient's specific condition if he gives the patient an appointunent for treatment of the specific problem. ${ }^{37}$ Acceptance of a referral can also create a duty. ${ }^{38}$ In summary, a physician cannot unilaterally refuse to care for a patient once a relationship has been initiated, unless the patient is stable and the physician gives sufficient notice of his intention to withdraw from the relationship.

The doctrine of abandonment will have an important role in determining doctors' legal duties in treatment of AIDS patients. If a physician is treating a patient who has AIDS, he cannot withdraw from that relationship because of the disease status of the patient, unless he first gives ample warning and recominends another physician. Moreover, the physician cannot withdraw if the AIDS patient is ill. AIDS patients are frequently ill, and many times the ilhress is critical. Does this inean that once a physician enters a relationship with an AIDS patient, he is coinmitted to treatment of that patient for life? Some coininentators have answered this question in the affirmative, ${ }^{39}$ but I think this demonstrates

33. See McCoid, supra note 29 , at 556.

34. Ricks v. Budge, 91 Utah 307, 314-15, 64 P.2d 208, 211-12 (1937).

35. See, e.g., McGulpin v. Bessmer, 241 Iowa 1119, 1126-27, 43 N.W.2d 121, 125 (1950); Becker v. Janinski, 27 Abb. N. Cas. 45, 49, 15 N.Y.S. 675, 676 (Ct. Com. Pl. 1891).

36. See, e.g., Moeller v. Hauser, 237 Minn. 368, 381-82, 54 N.W.2d 639, 647 (1952); Vann v. Harden, 187 Va. 555, 565-67, 47 S.E.2d 314, 314-20 (1948); see McCoid, supra note 29, at 556-57 (delineating the contours of abandonment). See generally Note, The Action of Abandonment in Medical Malpractice Litigation, 36 TUL. L. REv. 834 (1962) (distinguishing abandonment from negligence action and reviewing defenses to abandonment charge).

37. Lyons v. Grether, 218 Va. 630, 633, 239 S.E.2d 103, 105 (1977).

38. See Davis v. Weiskopf, 108 Ill. App. 3d 505, 511-13, 439 N.E.2d 60, 64-65 (1982). Telephone discussion of a case does not create suclı a duty. See Buckroyd v. Bunten, 237 N.W.2d 808, 811 (Iowa 1976).

39. See, e.g., Banks, supra note 11, at 177 ("[W]hile the courts lave not imposed any general duty to treat on private physicians in the absence of some close connection to the patient, whether thcy will continue to adhere to the traditional "no duty' rule is open to question."). 
an incomplete understanding of the clinical course of AIDS. The disease tends to smolder and then flare with a new opportumistic infection. The majority of AIDS patients' clinical courses are quite stable at times; a new therapeutic relationship could be established during this stability without detriment to the patients' health. Thus the doctrine of abandonment does not necessarily prohibit physicians' withdrawal from relationships with AIDS patients.

The same is true with patients who are HIV seropositive. People who carry the HIV may be completely asymptomatic and require no therapy. ${ }^{40}$ While this patient has the potential to become quite sick, he or she is usually not acutely ill, and physicians can give proper notice of withdrawal with impunity.

Nor will the doctrine of abandonment prevent doctors from requesting antibody screening before they initiate care. If a practitioner establishes a clear policy against undertaking any care unless an antibody screening test is completed, it will be difficult to argue that a therapeutic relationslip has begun and that the doctor's refusal to care represents abandonment. If this kind of case arises in the future, courts may try to reinvent the abandoninent doctrine. Short of that, however, it is unlikely that the legal duty not to abandon patients will guarantee access to care for AIDS patients.

Moreover, abandoninent concerns only medical practitioners and their independent relationships with patients. Hospitals and other health care institutions are governed by a completely different set of doctrines that derive from both the common law and statutory law. Because inore and nore physicians are employed directly by hospitals, ${ }^{41}$ these doctrines may guarantee access to both the nistitutions and the physicians employed therein.

The common law doctrine of reliance upon a gratuitous undertaking $^{42}$ has been extended to the emergency services of a hospital. In Wilmington General Hospital v. Manlove, ${ }^{43}$ a nurse had refused to adinit a child suffering from fever and diarrhea to the emergency ward pursuant to a hospital policy that a patient's illness had to evidence a frank emer-

40. See Goedert \& Blattner, supra note 1, at 22-23.

41. See generally Havighurst, The Changing Locus of Decision-Making in the Health Care Sector, 11 J. HEALTH POL. POL'y \& L. 697 (1986) (discussing relation of hospital and physicians).

42. Rehance upon a gratuitous undertaking was first described in railroad crossing cases. See, e.g., Erie R.R. v. Stewart, 40 F.2d 855, 857 (6th Cir.) (railroad neghigence estabhished where plaintiff knew of railroad's use of a watchman and relied thereon, and absence of watchman was totally unexpected), cert. denied, 282 U.S. 843 (1930).

43. 54 Del. 15, 17-18, 174 A.2d 135, 136-37 (1961). The triage nurse's refusal to evaluate the child no doubt played a role in the court's consideration of this case. See Dougherty, The Right to Health Care: First Aid in the Emergency Room, 4 PUB. L.F. 101, 105-07 (1984). 
gency. The Supreme Court of Delaware found a common law right to treatment "if the patient has relied upon a well-established custom of the hospital to render aid in such a case." 44 In effect, the court created a right to treatment at an emergency room for any genuine emergency. ${ }^{45}$

Courts have found means other than the common law to elaborate a right to emergency treatment-the most important of which is the scope of state regulation. For example, in Guerrero v. Copper Queen Hospital, 46 the Arizona Supreme Court ruled that private hospitals had to provide emergency care to all patients because Arizona law required all general hospitals to maintain emergency rooms. ${ }^{47}$

In 1980, the statutory and common law grounds were consolidated in Hiser v. Randolph. ${ }^{48}$ In this case, the plaintiff's wife had arrived in the Mohave County General Hospital suffering from diabetic ketoacidosis, a life-threatening condition to which young diabetic adults are prone. The physician on call refused to come to the hospital and attend to the plaintiff, who subsequently died. In the ensumg hitigation, the defendant-physician claimed he had no relationship with the diabetic patient and thus owed her no duty. In rejecting his arguinent, the court cited Guerrero, alluded to a common law duty, and referred to the American Medical Association Code of Ethics, which directs physicians to render service in emergency situations. ${ }^{49}$ Hiser thus set forth the duty of hospitals that staff emergency rooms provide care for all emergencies, as well as the duty of physicians who work in such emergency rooms to care for acutely ill patients. ${ }^{50}$

44. Manlove, 174 A.2d at 140 . It is debatable whether the court's reliance on section 323 of the Restatement (Second) of Torts is appropriate in this context. See Comment, The Private Hospital's Role in the Dumping of the Indigent Emergency Patient, 4 PUB. L.F. 141, 148-49 (1984) (accusing Manlove court of misinterpreting the Restatement's idea of "gratuitous undertaking").

45. Manlove has been followed in a variety of other jurisdictions. See, e.g., Hill v. Ohio County, 468 S.W.2d 306, 309 (Ky. 1971) (no breach of duty by hospital where "decedent was not admitted to the hospital nor was the elenent of critical emergency apparent"), cert denied, 404 U.S. 1041 (1972); Stanturf v. Sipes, 447 S.W.2d 558, 562 (Mo. 1969) (reinanding to determine whether facts rose to level of Manlove "ennergency").

46. 112 Ariz. 104, 106, 537 P.2d 1329, 1331 (1975).

47. In a concurring opinion, the Vice Chief Justice rejected the statutory ground established by the majority, bnt agreed with the outcome based on his acceptance of Manlove. Id. at 107, 537 P.2d at 1334 .

48. 126 Ariz. 608, 617 P.2d 774 (Ct. App. 1980).

49. Id. at $611-12,617$ P.2d at 777-78. For more details on the case, see Dougherty, supra note 43 , at 116-17.

50. Another trend in the common law has been to rcason that hospitals assume a risk of hability when they decide to render emergency services. See New Biloxi Hosp., Inc. v. Frazier, 245 Miss. 185, 197, 146 So. 2d 882, 887 (1962); Note, To Treat or Not To Treat: A Hospital's Duty to Provide Emergency Care, 15 U. CAL. DAvis L. REv. 1047 (1982).

Some counmentators also have argued that the Joint Commission for Accreditation of Hospitals regulations, JoInt Commission on ACCREDITATION OF Hosprtals, THE ACCREDITATION MAN- 
Unfortunately, the right to emergency care at a hospital that offers emergency services does hittle to guarantee that people with AIDS will have unfettered access to health care. If an AIDS patient is suffering from a medical emergency, it is rather clear that he or she has a legal right to care in a hospital with an emergency service. But the cases cited above provide hittle more than that-emergency care. Once the acute medical problem stabilizes, the hospital appears to be able to sever its relationship. ${ }^{51}$ The same is true for any physicians or other health care workers who are involved in the patient's care. ${ }^{52}$ If this is all the law offers, then we must conclude that it is madequate.

There may, however, be other means for guaranteeing access to health care for AIDS patients. Certain federal statutory provisions have been interpreted as providing rights of access to health care. Foremost among these provisions is the Hill-Burton Reconstruction Act. ${ }^{53}$ The original act was a post-War measure designed to create employment and provide better health care through hospital construction grants. ${ }^{54}$ In return for the grant funds, the private hospitals were expected to provide services for some indigent patients. This quid pro quo was convemiently ignored by hospitals throughout the 1950s and 1960s. ${ }^{55}$ In the 1970s, however, hitigation about the Act developed a right to health care for indigent people at Hill-Burton facilities. ${ }^{56}$

In response to these cases, the Department of Health and Human

UAL FOR HOSPITALS 23-34 (1980), require that hospitals offer emergency service for all. See Comment, supra note 44, at 156.

51. See Banks, supra note 11, at 180.

52. See, e.g., Harper v. Baptist Medical Center-Princeton, 341 So. 2d 133, 134 (Ala. 1976) (no duty of care because not emergency). Of course, the patient must be stable. "Dumping" of acutely ill patients from one hospital to another is governed by the common law doctrine of negligence. See Hunt v. Palm Springs General Hosp., Inc., 352 So. 2d 582, 585 (Fla. Dist. Ct. App. 1977).

53. Hospital Survey and Construction Act, Pub. L. No. 79-725, 60 Stat. 1040 (1946) (codified as amended at 42 U.S.C. $\$ 291$ (1982)); cf. Curran, Medical Charity for the Poor: Hill-Burton and the Hospitals, 287 NEW ENG. J. MED. 498, 498-99 (1972) (discussing hospitals' obligation under proposed supplemental regulations to Hill-Burton).

54. See Blumstem, Court Action, Agency Reaction: The Hill-Burton Act as a Case Study, 69 Iowa L. Rev. 1227, 1229 (1984). See generally Rose, Federal Regulation of Services to the Poor Under the Hill-Burton Act: Realities and Pitfalls, 70 Nw. U.L. Rev. 168 (1975) (discussing legislative history and implementation of Act); Note, The Hill-Burton Act, 1946-1980: Asynchrony in the Delivery of Health Care to the Poor, 39 MD. L. REv. 316 (1979) (examining the policy issues raised by development of Act).

55. See Note, Due Process for Hill-Burton Assisted Facilities, 32 VAND. L. REv. 1469, 1472 (1979).

56. See, e.g., Newsom v. Vanderbilt Univ., 453 F. Supp. 401, 423 (M.D. Tenn. 1978) (imdigent persons have constitutional riglt to uncompensated needed services under Act), aff'd in part, modified in part, and rev'd in part, 653 F.2d 1100 (6th Cir. 1981) (rejecting district court's finding of entitlement for any individual indigent; finding mstead that Act only required the provision of a reasonable volume of free services to indigents as a class). See generally Blumstem, supra note 54 (examining Act's evolution). 
Services promulgated new regulations, ${ }^{57}$ requiring Hill-Burton hospitals to render a certam amount of uncompensated care to imdigent patients each year and to make the facility available to all who reside within a certain area. The latter requirement-referred to as the "community service" requirement ${ }^{58}$-means that hospitals cannot discriminate on the basis of race, color, national origin or any other ground unrelated to the individual's need for care. ${ }^{59}$

One could argue that the commumity service requirement would prohibit private hospitals that have accepted Hill-Burton funds from restricting access to patients who have AIDS or who are seropositive. Such restrictions could be construed as discrimination on a basis other than need. A private hospital that imstituted these restrictions would probably argue that the restrictions have a rational basis. Moreover, Hill-Burton hospitals are required only to fill a certain quota with regard to indigent care; after that quota is filled, any mandate to provide care lapses. ${ }^{60}$ It is also difficult to understand how the Hill-Burton Act could be used to prohibit a screening program in nonemergency cases-unless the program led to selective discrimination. Thus while it is clear that the Hill-Burton Act provides some guaranteed access to health care beyond the emergency room, the scope of the access is unclear.

Other federal constitutional and statutory antidiscrimination laws may prevent hospitals from developing restrictive policies. The fourteenth amendment's equal protection clause prevents public hospitals from imposing selective burdens on people uuless there is a rational relationship to a legitimate objective. ${ }^{61}$ Thus the risk to health care workers posed by HIV seropositive individuals would have to be great enough such that any restrictions on care would be considered rational. All hospitals that receive Medicare payments are under similar restrictions. Title VI of the Civil Rights Act prohibits discrimination at facilities that

57. 42 C.F.R. $\S \S 124.501-.607$ (1979). Professor James Blumstein argues that these regulations embraced the tenets of the plaintiffs' litigation of the previous eight years, but not the legislative history of the Act. See Blumstein, supre note 56, at 1245-49.

58. See Wing, The Community Service Obligation of the Hill-Burton Health Facilities, 23 B.C.L. REV. 577 (1982).

59. See 42 C.F.R. $\S 124.603(a)(1)$ (1988). Litigation has done little to affect the scope of these regulations. See, e.g., American Hosp. Ass'n v. Schweiker, 721 F.2d 170, 172 (7th Cir. 1983) (community service regulations upheld against statutory, contractual and constitutional claims), cert. denied, 466 U.S. 958 (1984); Newsom, 653 F.2d at 1115.

60. Comment, supra note 44, at 153.

61. See Floyd v. Willacy County Hosp. Dist., 706 S.W.2d 731, 736 (Tex. Ct. App. 1986) (selective restrictions on hospital admission upheld if rationally related to legitimate state interest); Note, Floyd v. Willacy: Hospital Policy Prognosis-Complications Caused by TTCA and Equal Protection, 39 BAYLOR L. REV. 573, 586-93 (1987). 
receive federal assistance. ${ }^{62}$ The ambit of Title VI in the health care field has not been well described, ${ }^{63}$ but AIDS discrimination might change this.

The Rehabilitation Act of 1973 (the Act) also may help ensure access for AIDS patients or those who are HIV seropositive. The Act prohibits discrimination against handicapped persons. ${ }^{64}$ In a case closely followed by those interested in the rights of AIDS patients, the Supreme Court classified a school teacher with tuberculosis as handicapped under the Act and characterized her firing as irrational and discriminatory. ${ }^{65}$ Under this approach, hospitals receiving federal funds will be prohibited from discriminating against HIV seropositive individuals and patients with AIDS, unless any restrictions on care are rational.

If courts analyze hospitals' policies under these federal statutes, then such policies cannot be based on hysteria alone, but must bear a rational relationship to the prevention of occupationally contracted HIV infection. Determining what is rational will be difficult. Physicians and hospitals may be able to convince courts that restrictions unake sense in hight of the sinall but not negligible risks of infection. This question will be answered if such policies become widespread and litigation occurs. Of course, any facility or person who does not receive federal funds is not required to comply with such federal prescriptions. ${ }^{66}$

Another manner of prohibiting discrimination against patients with AIDS is through the promulgation of local ordinances and state laws. Some cities have already passed laws that specifically prohibit discrimi-

62. 42 U.S.C. $\$ 2000 d$ (1982).

63. See Wing, Title VI and Health Facilities: Forms Without Substance, 30 HASTINGs L.J. 137, 137-38 (1978); see also NAACP v. Medical Center, Inc., 657 F.2d 1322 (3d Cir. 1981) (relocation of medical center from city to suburbs did not violate Title VI); Bryan v. Koch, 627 F.2d 612 (2d Cir. 1980) (closing hospital that served large minority population did not violate Title VI).

64. 29 U.S.C. $\$ 794$ (1982).

65. School Bd. v. Arline, 107 S. Ct. 1123 (1987). Arline is a considerable advance; it provides advocates of unfettered access to health care for AIDS patients with a viable strategy and means for fighting restrictions. It nonetheless is limited. As Wendy Parmet notes, "The inajor problem is the simple fact that unlike most handicaps, infectious diseases can be transmitted to others. The key questions are: What should that mean? And how much risk should be tolerated?" Parmet, AIDS and the Limits of Discrimination Law, 15 LAw MED. \& HEALTH CARE 61, 67 (1987). See generally Leonard, AIDS and Employment Law Revisited, 14 HoFSTRA L. REV. 11 (1985) (reviewing legal issues raised by AIDS-based discrimination in the workplace); Note, AIDS: Does It Qualify as a 'Handicap' Under the Rehabilitation Act of 1973?, 61 NoTRE DAME L. REV. 572 (1986) (justifying classification of AIDS victims as "handicapped" for purposes of Rehabilitation Act of 1973).

66. It is doubtful that any major hospitals can afford to drop out of Medicare and Medicaid programs. Individual doctors can and do forego federal reimbursements that are available with physician acceptance of certain restrictions. 
nation against people with AIDS. ${ }^{67}$ In addition, many states and municipalities have general antidiscrimination statutes to protect handicapped individuals, ${ }^{68}$ which may be interpreted as banning discrimination in doctors' offices and hospitals. ${ }^{59}$ The scope of such statutes and the definition of discrimination they employ will have to be defined by clear statutory language and litigation.

If the epidemic continues to grow and the anecdotal reports of occupational spread of the disease persist, the number of restrictive policies could mushroom. The common law duties imposed on doctors and certain hospitals and federal antidiscrimination law take us only partway to guaranteeing full access to health care for those infected with HIV.70 Perhaps, however, a legal solution is unnecessary. If doctors and other health care workers have an ethical duty to care for all patients regardless of disease, then a legal solution is not needed. Medical ethics thus may close the gaps left by the law in guaranteemg access to care for AIDS patients.

\section{B. An Ethical Duty to Treat.}

Health care workers serve as doctors, nurses, nursing assistants, orderlies, transport personnel, food service workers, and maintenance people, and in a variety of other occupations. While all of these workers may have some risk of acquiring the HIV in their workplace, they do not all have a self-assumed ethical duty to care for patients with AIDS. Most hospital administrators would consider a hospital employee's decision not to care for AIDS patients a matter of free choice, but one that probably calls for termination of employment. ${ }^{71}$

Doctors and nurses are members of professions that have longstand-

67. E.g., San Francisco Police Code, 3081 cited in Banks, supra note 11, at 178 n.27; see also Executive Order Issued in Minnesota: Governor Prohibits State from AIDS Discrimination, Am. Med. News, Jan. 9, 1987, at 39.

68. See Banks, supra note 11 , at 178 .

69. See Washington State Human Rights Comm'n, Statement of Policy: AIDS and Public Accommodation (draft 1986), cited in Banks, supra note 11, at 178 n.26.

70. In addition to the legal theories discussed above, several other means for creating a legal duty to treat exist. For example, one could argue that nonprofit hospitals must provide care without discrimination, or they will risk losing nonprofit status granted by the Internal Revenue Service. See I.R.C. $\$$ 501(c)(3) (1982); see also Banks, supra note 11, at 180 n.54. But see Simon v. Eastern Ky. Welfare Rights Org., 426 U.S. 26, 45 (1976) (no standing for organization challenging I.R.S. ruling granting tax exempt status to hospital that refused emergency service to poor people). Another means for creating a legal duty might be the anti-dumping provisions of the Hill-Burton Rcconstruction, 42 U.S.C. $\$ 291(c)(3)(1982)$. See Comment, supra note 44, at 152.

71. See Staver, New Resources Must be Summoned in AIDS Fight, Conference Stresses, Am. Med. News, Oct. 23/30, 1987, at 2, 33 (quoting Dr. Robert L. Cohen, vice president for medical operations of the Health and Hospitals Corporation of the City of New York: "Within New York's public hospitals, workers who refuse to [care for AIDS patients] will be fred ...."). 
ing traditions of ethical behavior and well-developed ethical codes.72 Some physicians have stated unequivocally that medical ethics requires that physicians provide care for AIDS patients. ${ }^{73}$ Such a position raises two questions: (1) is it true that medical ethics requires physicians to care for any patient, including AIDS patients, and (2) if so, will all doctors act according to this ethical duty?

To answer these questions, we first must understand the nature and scope of medical ethics. This is no easy task-even, or especially, for those of us who are members of the medical profession. Most medical students receive no formal training in ethics. Many never even utter an oath, Hippocratic or otherwise. Although the American Medical Association publishes a code of ethics, the majority of physicians in this country are not inembers. While an entire academic field has grown up around the term medical ethics in the last two decades, its reaction to and impact on medical practice is unclear.

Indeed, it is not possible to talk about a single medical morality or a theory of medical ethics. ${ }^{74}$ The variety of the codes, essays and ethical and moral assumptions put forth as medical ethics is enormous. Nonetheless, certain values or ideals are common to many renditions. These values or ideals center on the physician's responsibility to the patientthe attitude that a physician acts morally when he or she places the patient's welfare above all other considerations. Whether characterized as a principle of beneficence, non-malfeasance, autonomy or justice, the guiding principle is that the patient's welfare comes before all other considerations. ${ }^{75}$

Paul Ramsey has developed his sense of medical ethics by reference to notions of covenant and fidehty. ${ }^{76}$ Ramsey argues that a physician must be selfless in her relationship with the patient or, "[i]n the language of philosophy, a deontological dimension or test holds chief place in med-

72. For the purposes of this article, I will discuss the role of physicians' behavior and medical ethics. Nursing ethics may be broadly similar.

73. For example, Dr. Paul Volberding, director of AIDS activities at San Francisco General Hospital, and Dr. Donald Abrams, assistant director of the AIDS Clinic, San Francisco General Hospital, stated that refusal to work with AIDS patients is a "clearly unethical stance." Volberding \& Abrams, Clinical Care and Research in AIDS, 15 Hastings CENTER REP., Aug. 1985 Special Supp., at 16.

74. As Veatch notes, "[t]o be realistic about it, 'theories of medical ethies' is too pretentious. What we really have before us is a series of unsystematic, unreflective, ethical stances, or traditions." R. Veatch, A Theory of Medical Ethics 5 (1981).

75. See generally T. Beauchamp \& J. Childress, Principles of Biomedical Ethics 21 (1983) (practice should be ruled by doing what is best for greatest number of people).

76. See P. Ramsey, The Patient as Person: Explorations in Medical Ethics $x i i$ (1970). 
ical ethics, beside teleological considerations." 77 Ramsey puts the doctor-patient relationship outside of the liberal and utilitarian principles that usually guide behavior in our country, noting that "partnership is a better term than contract in conceptualizing the relation between patient and physician." 78 He believes that "faithfulness among men-the faithfulness that is normative for all the covenants or moral bonds of life with life-gains specification for the primary relations peculiar to medical practice."79

Other commentators have argued that this special ethical relationship has been diminished by efforts to advocate patients' rights. Mark Siegler, for instance, argues that the "imposition of rights language might supplant the traditional model of medicine-a covenantal model premised on promise keeping ... and replace it with a narrowly contractual model based on libertarian principles of self-determination."80 Indeed, as the economic orgamzation of health care has changed, so too has the dominant role of the physician in the provision of health care. ${ }^{81}$ Patients' demands for informed consent, ${ }^{82}$ increasing malpractice hitigation, ${ }^{83}$ efforts by government and thircl party payers to restrict therapeutic prerogatives, ${ }^{84}$ growth of "for profit" medicine, ${ }^{85}$ and the increasmg role of

77. Id. at 2. The mutuality of the doctor-patient relationship as discussed by Ramsey derives directly from Kantian notions of ethical relationships. In these terms, the patient must be treated as an end in himself, not as a means. I. KANT, GROUNDWORK TO THE METAPHYSICS OF MORAIS 61 (Paton ed. 1950). Bernard Williams has written that "each man is owed the effort of understanding, and that in achieving it, each man is to be (as it were) abstracted froun certain conspicuous structures of inequality in which we find him." Williams, The Idea of Equality, in JUSTICE AND EQUALITY 116,125 (H. Bedau ed. 1971). Thus the AIDS patient should be abstracted from the fact of biological contagiousness and treated as any other patient.

78. P. RAMSEY, supra note 76, at 6; cf. Entralgo, Fomay Relidad de Hippocrates, 23 FoliA Clinica InTERnacional 15 (1968); Jansen \& Hellegers, Conceptual Foundations for an Ethies of Medical Care, in Ethics AND Health Policy ch. 2 (R. Veatch \& R. Branson eds. 1976) (Medical ethics inust consist of theories of virtue, duties, and justice.).

79. P. RAMSEY, supra note 76, at 5 .

80. Siegler, A Right to Health Care: Ambiguity, Professional Responsibility, and Patient Liberty, 4 J. MED. \& PHIL. 148, 154 (1979).

81. See Havighurst, supra note 41 , at $698,711,713$.

82. See generally J. KATz, The Silent World of Doctor and Patient (1984); A. Rosoff, InFormed CONSENT: A GuIDe for Hisalth CARE Providers (1981); Katz, Informed ConsentA Fairy Tale? Law's Vision, 39 U. PrrT. L. Rev. 137 (1977); Meisel, The "Exceptions" to the Informed Consent Doctrine: Striking a Balance Between Competing Values in Medical Decisionmaking, 1979 WIS. L. REv. 413.

83. See Danzon, The Frequency and Severity of Medical Malpractice Claims: New Evidence, LAW \& ConTEMP. Probs., Spring 1986, at 57-58, 63-68.

84. See Havighurst, supra note 41, at 721-22; see also P. StarR, The Social Transformation of AMErican Medicine (1982); Brown, Competition and Health Cost Containment: Cautions and Conjectures, 59 Millbank MEmorial Fund Q. 145 (1981); Iglehart, The New Era of Prospective Payment for Hospitals, 307 NNEw ENG. J. MED. 1288, 1292 (1982).

85. See Iglehart, Health Policy Report: Health Care and American Business, 306 NEw ENG. J. MED. 120, 120 (1982); Marmor, Boyer \& Greenberg, Medical Care and Procompetitive Reform, 34 
doctor as an employee of a hospital or health maintenance organization ${ }^{86}$ have all led to what physicians have termed a "deprofessionalization" of medicine. ${ }^{87}$

Many of these changes have increased the quality of health care. Moreover, they have helped overcome the paternalism of the medical profession and have empowered patients. ${ }^{88}$ Physicians can no longer assume that they can make all of the decisions in the doctor-patient relationship. By reintegrating medicine into the fabric of the liberal states, lowever, these changes may liave diminisled the doctor's sense of commitment to the patient. Thus the medical ethics of the 1980s may not be the covenant/fidelity model suggested by Ramsey.

Robert Sade argues that physicians slould approach the practice of medicine from a libertarian point of view. ${ }^{89}$ Relying on Locke, Sade argues thiat a doctor's ability to care for patients can be sold or not sold, depending on the doctor's clioice. He states tliat as a result there can be no such thing as a right to liealth care..$^{90}$

A corollary, whicl sade does not acknowledge, is that the relationship between doctor and patient is a contractual one. This may seem foreign to some physicians. However, to a recent medical scliool graduate who was lucky to get a job witlı an HMO in an urban center, who works defined shifts, wlio gets incentive pay for seeing more patients as well as gettimg lis patients out of the hospital in a liurry, who does not paternalistically act without the patient's full consent, who follows strict quality assurance guidelines policed by his employer, and who may be

VAND. L. Rev. 1003, 1016-21 (1981); Saward \& Sornensen, Competition, Profit and the HMO, 306 NEW ENG. J. MED. 929, 930-31 (1982).

86. See A. Enthoven, Health Plan: The Only Practical Solution to the Soaring Cost of Medical Care ch. 4 (1980); H. Luft, Health Maintenance Organizations: Dimensions of Performance ch. 12 (1981); Relman, Investor-Owned Hospitals and Health-Care Costs, 309 NEW ENG. J. MED. 370, 370 (1983) (noting increased concentration of hospital ownership in a few large investor-owned chains); Tarlov, Special Report: Shattuck Lecture--The Increasing Supply of Physicians, the Changing Structure of the Health-Services System, and the Future Practice of Medicine, 308 NEW ENG. J. MED. 1235, 1238-41 (1983) (noting "industrialization" of nedical practice).

87. See McKinlay \& Arches, Toward the Proletarianization of Physicians, 15 INT'L J. HeAlTH Servs. 161 (1985); Reed \& Evans, The Deprofessionalization of Medicine: Causes, Effects, and Responses, 258 J. A.M.A. 3279 (1987).

88. Some commentators have argued that medical ethics has increased and supported physicians' nonopoly over health care and has helped physicians increase profits accordingly. See, eg.,

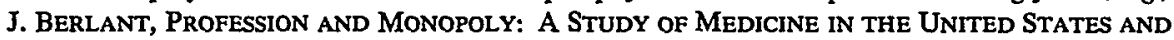
GREAT BRITAIN ch. 3 (1975) ("Ethics have been used to help order the conduct of physicians in a inonopolistic direction, yet they have also been used to help make the profession appear less inonopolistic for a variety of political reasons.").

89. See Sade, Medical Care as a Right: A Refutation, 285 New ENG. J. Med. 1288, 1289 (1976).

90. Id. 
involved in a profit-sharing plan with the HMO, the concept of the doctor-patient relationship as a contractual one is not very foreign at all. Of course, as many philosophers have pointed out, the doctor-patient relationship can never be truly contractual. ${ }^{91}$ Nonetheless, the present nature of medical ethics is ambiguous and refiects the major changes in the health care industry that have occurred over the last decade.

The ambiguity in the current nature of inedical ethics is obvious when one reviews the debate presently occurring in the medical literature about the ethics of caring for AIDS patients. Edmund Pellegrino has argued that the concern about AIDS contagion gives physicians the chance to reiterate their self-effacement and reaffirm the altruism at the heart of medical practice. ${ }^{92} \mathrm{He}$ says physicians have no other choice because of the nature of illness itself, and because physician knowledge is not proprietary and doctors take an oath. ${ }^{93}$ In effect, Pellegrino demies Sade's central proposition-that physicians are in the marketplace and are free to contract. ${ }^{94}$ Less articulate physicians who support restrictions on patients with AIDS, or at least support unrestricted HIV antibody testing, note simply that "[w]hen it comes to iny ethics or my life, you know what side I'm going to vote on. . . . Self-preservation comes first." 95

The American Medical Association's (AMA's) current debate over HIV testing and refusal to care for AIDS patients also reveals the difference of opinion that exists on the scope of medical ethics. The AMA Council on Ethical and Judicial Affairs recently published a report that condemned the refusal to care as unethical and stated that those who are HIV seropositive should not be the subject of any form of discrimination. ${ }^{96}$ This report led to "vociferous and sometimes angry ... debate"

91. See Outka, Social Justice and Equal Access to Health Care, Perspectives in BIOLOGY \& MED., Winter 1975, at 185; Masters, Is Contract an Adequate Basis for Medical Ethics?, HASTINGS Center ReP., Dec. 1975, at 24, 25-27.

92. Pellegrino, Altruism, Self-Interest, and Medical Ethics, 258 J. A.M.A. 1939, 1939 (1987); see also Zuger \& Miles, Physicians, AIDS, and Occupational Risk: Historic Traditions and Ethical Obligations, 258 J. A.M.A. 1924 (1987) (historic tradition of ethical obligations in the face of pestilence is confused; current "rights model" and contract model leave great leeway; only less familiar but preferable virtue-based model requires treatment of AlDS victims).

93. Pellegrino, supra note 92, at 1939.

94. See Sade, supra note 89, at 1289 . Pellegrino's first reason has been argued by Outka, again in opposition to Sade's understanding of medical practice. Outka, supra note 90, at 194. As far as Pellegrino's third reason is concerned, most physicians do not recall uttering Hippocrates' oath, although oaths are frequently used during one's medical training.

95. Samir Ragheb, M.D., quoted in Pinkney, CDC: Health Worker AIDS Risk from Needle Is Less Than 1\%, Am. Med. News, Dec. 18, 1987, at 37, 37. For a topical discussion of the fears voiced by health care workers, see Scott, Fear in the Foxholes, NEw YoRK MAG., Jan. 4, 1988, at 28.

96. See Staver, Unethical to Refuse to Treat HIV-Infected Patients, AMA Says, Am. Med. Ncws, Nov. 20, 1987, at 1. 
at an AMA House of Delegates meeting. ${ }^{97}$ One plastic surgeon stated he would continue to require testing and would refuse to do cosmetic surgery on HIV seropositive individuals because the AMA policy was "wrong."98 Another delegate predicted mass defection from the AMA if the report remains AMA policy.99

Indeed, the AMA's Principles of Medical Ethics clearly state that a "[p]hysician shall, in the provision of appropriate patient care, except in einergencies, be free to choose whom to serve, with whom to associate, and the environment in which to provide medical services." 100 Thus, the AMA policy may be at odds with its own principles of ethics.

The debate about the role of medical ethics in the prevention of discrimination against AIDS patients or those who are seropositive for HIV is not over. It would be a great day for the medical profession if it were able to guarantee access to liealth care for all people with AIDS, AIDS Related Complex, or who are HIV seropositive by reaffirming its duty to care for all patients in an altruistic manner. Given the tenor of the current debate, however, I am not confident that this will liappen.

What is inost likely is that a group of physicians will decide they have a duty to care for all people and will refuse to test or discriminate, perliaps at soine personal peril. Despite the possible risks, it is very important, from a liealth pohicy point of view, to encourage as many physicians as possible to join this group. The best way to do so is to ensure that the cost of a hospital accident that leads to occupationally related AIDS is not borne solely by the liealth care worker and lier or his family. If compensation for occupationally related AIDS is available, more physicians and lealth care workers will be able to heed their altruistic impulses.

\section{Bearing the Costs of Occupationally Related AIDS}

A. The Costs of Accidents.

If a health care worker contracts the HIV at his workplace, he will

97. Staver, Delegates File Report on AIDS Ethical Issues, Am. Med. News, Dec. 18, 1987, at 48.

98. The surgeon conceded that he will continue to perform "all medically necessary procedures on HIV-positive patients." Id. (statement of Donald Moyhihan, MD, alternate delegate, Vero Beach, Florida).

99. Id. (statement of William L. Smith, MD, alternate delegate, Jefferson County, Alabama).

100. Principles of Medical Etrics principle 5 (1980), reprinted in Council on Ethical and Judicial Affairs, CuRrent Opinions of the Council on Ethical and Judicial AFFaIRS OF THE AMERICAN MEdical Association ix (1986). Berlant would argue that this kind of principle does not so much create altruistic behavior as it maintains the hegemony of the profession over the means of practice. J. BERLANT, supra note $88, \mathrm{ch} .3$. 
probably be seropositive for life. ${ }^{101}$ In addition, the infected worker stands about a $70 \%$ chance of developing AIDS within seven years. ${ }^{102}$ The first inanifestations may be subtle impairment of the central nervous systen. ${ }^{103}$ Once the clinical inanifestations of AIDS develop, the mean survival is approximately two years, with five-year inortality approaching $100 \% .{ }^{104}$

Tremendous costs will be associated with these accidents-both in economic and emotional terms. ${ }^{105}$ The total economic cost of providing medical care for a person with AIDS has been estimated at $\$ 147,000 .{ }^{106}$ Once this person dies, his family and dependents will need financial support. ${ }^{107}$

Determining who will bear these costs is vitally important to guaranteeing access to health care for those who are seropositive. If those

101. See Zagury, Bernard, Leonard, Cheynier, Feldman, Sarin \& Gallo, Long-Term Cultures of HTL V-III-Infected T Cells: A Model of Cytopathology of T-Cell Depletion in AIDS, 231 SCIENCE 850 (1986).

102. See Goedert, Biggar, Weiss, Eyster, Melbye, Wilson, Ginzburg, Grossman, DiGioia, Sanchez, Giron, Ebbesen, Gallo \& Blattner, Three-Year Incidence of AIDS in Five Cohorts of HTLVIII-Infected Risk Group Members, 231 SCIENCE 992 (1986) (34.2\% in cohort of homosexual males in Manhattan, $14.9 \%$ in other four cohorts). Almost all those infeeted have a two to three year quiescent period in which they are infectious but asymptomatic. Melbye, Biggar, Ebbeson, Neuland, Goedert, Faber, Lorenzen, Skinhoj, Gallo \& Blattner, Long-Term Seropositivity for Human TLymphotropic Virus Type III in Homosexual Men Without the Acquired Immunodeficiency Syndrome: Development of Immunological and Clinical Abnormalities, 104 ANNALS INTERNAL MED. 496 (1986).

103. Goudsmit, Wolters, Bakker, Smit, VanderNoordaa, Hische, Tutuarima \& Van der Helm, Intrathecal Synthesis of Antibodies to HTLV-III in Patients Without AIDS or AIDS Related Complex, 292 BRIT. MED. J. 1231 (1986); Grant, Atkinson, Hesselink, Kennedy, Richman, Spector \& McCutchan, Evidence for Early Central Nervous System Involvement in the Acquired Immunodeficiency Syndrome (AIDS) and other Human Immunodeficiency Virus (HIV) Infections, 107 ANNALS INTERNAL MED. 828 (1987).

104. Because the epidemic has not yet matured, it is difficnlt to estimate the survival for the various risk groups that make up the AIDS patient population. However, we do know that as of January 1, 1986, AIDS patients diagnosed before 1983 had a $77 \%$ inortality, those diagnosed in 1983 had a $73 \%$ mortality, those diagnosed in 1984 had a $61 \%$ mortality, and those diagnosed in 1985 had a $31 \%$ mortality. Castro, Hardy \& Curran, The Acquired Immunodeficiency Syndrome: Epidemiology and Risk Factors for Transmission, 70 MED. CuINICs N. AM. 635, 639 (1986).

105. I will not be able to discuss in detail the enotional costs of contracting AIDS. For a closer examination, see Cassens, Social Consequences of the Acquired Immunodeficiency Syndrome, 103 AnNals INTERNal MEd. 768 (1985); Nichols, Psychosocial Reactions of Persons with the Acquired Immunodeficiency Syndrome, 103 ANNALS INTERNAL MED. 765 (1985).

106. Hardy, Rauch, Echenberg, Morgan \& Curran, The Economic Impact of the First 10,000 Cases of Acquired Immunodeficiency Syndrome in the United States, 255 J. A.M.A. 209, 210 (1986).

107. The cost of replacing a healthy working person's incoine over the course of his expected life span is substantial. See P. Weiler, Legal Policy for Workplace Injuries 44-50 (Aug. 1985) (tentative draft report for the American Law Institute). The problem of infection spread by asymptomatic hosts is not yet apprecicated. The Public Health Service estimates there are between 1 and 1.5 million carriers of the HIV. See Young, Letter From The Commissioner, 17 FDA DRUG BULLETIN 14, 14 (1987). 
who are infected at the workplace are expected to bear the costs, they may seek safer employment elsewhere, thus driving up labor costs for hospitals and creating new incentives for hospitals to discriminate against seropositive individuals. Moreover, if physicians beheve they and their families will not be financially protected if an occupational HIV infection occurs, they will insist on testing patients or refuse to care for those who are seropositive.

The costs of accidents traditionally have been allocated by private insurance and tort law. ${ }^{108}$ Health, life and disability insurance are purchased by individuals or by third parties such as employers who provide benefits for employees. Private insurance partially defrays the cost of accidents, but in no way supplants tort hitigation. While the tort systein remains the inain arbiter of such costs, a no fault administrative approach supplants torts in most jurisdictions in cases of workplace injury. ${ }^{109}$ Workers' compensation laws cover about $87 \%$ of the work force in the United States. ${ }^{110}$ Thus, because they can allocate the costs of occupationally-related AIDS accidents, a discussion of private insurance, tort law and workers' compensation is needed to assess the manner in which the costs of these accidents can be properly diffused within society.

\section{B. Private Insurance.}

People who contract HIV can expect to go through several stages of disease developinent, with at least a theoretical possibility that the disease may arrest in any one stage. First, they will experience an asymptomatic period in which they merely carry the virus. Then a period of chronic fatigue and lymphadenopathy called the AIDS Related Complex intervenes. Finally, full-blown AIDS occurs, often manifested initially by neurological changes.

These various stages would require different types of insurance if insurance were to help shift the cost of an occupational HIV infection from the health care worker. The asymptonatic carrier stage may disable a person whose occupation creates the risk that others could contract the disease. This would be the case of a surgeon, who would then turn to disability benefits. During the AIDS Related Coinplex stage, most people would be disabled, and would also begin to seek nredical

108. See W. Keeton, D. Dobrs, R. Keeton \& D. OWen, Prosser \& Keeton on the LaW of TORTs 5-6 (5th ed. 1985) [hereinafter Prosser \& Keeton]. See generally G. Calabresi, The Costs of ACCIDENTS: A Legal AND Economic ANALysis (1970); R. Posner, Economic ANALYSIS OF LAW $\$ \$ 6.1,6.10-14$ (3d ed. 1986).

109. For a history of the development of workers' compensation, see generally Friedman \& Ladinsky, Social Change and the Law of Industrial Accidents, 67 CoLUM. L. Rev. 50 (1967).

110. J. Chelius, Workplace SaFety and Health: The Role of Workers' CompensaTION 20 (1977). 
care, creating a demand for benefits under health insurance. Finally, during the AIDS stage, health, disability and eventually life insurance benefits would be required.

Does insurance provide inore than a theoretical answer to the problem of the costs of HIV accidents for health care workers? The answer is a provisional yes. While inore than $75 \%$ of Americans have soine form of health insurance, and inany have life insurance, inany fewer have disability insurance. 111 Thus health care workers would not necessarily be covered for all the economic repercussions of HIV infection. Hospitals could, however, broaden the coverage they offer as terms of employment and provide disability and life insurance for employees as a benefit. It would be prudent for hospitals to take this last step in the near future.

The insurance approacli works as long as the insurance is available and the benefits are at an appropriate level. One would expect underwriters to develop policies along these lines for hospitals if the occupational risk is small and the insurers' actuaries are able to assess risk. Indeed, one would hope that actuaries would be immune to irrational fears, and that the insurance approach would be a cornerstone of a reasonable approach to shiftimg the costs of accidents.

One still inust ask what will happen if the estimate of the occupational risk continues to grow, and insurers grow uncertain about the policies they have been underwriting. Would it be possible for insurers to refuse to write new health, clisability or life insurance policies for health care workers? Again the answer is a provisional yes, depending on how the state governments react, and the manner in which the state courts view such decisions.

Insurers, their decisions about coverage, and the rates they set are governed by the various states. Since the late 1940s, most states have had insurance coinmissioners or other state agencies that oversee the insurance business. ${ }^{112}$ Most state insurance regulatory agencies are guided by the National Association of Insurance Cominissioners' model statute, which requires insurers to set rates that are not inadequate, excessive or unfairly discriminatory. ${ }^{113}$ With regard to life and disability insurance, and generally health insurance, ${ }^{114}$ the insurers are guided by this general

111. See K. Abraham, Distriburing Risk, 227 (1986).

112. The United States Supreme Court held, in United States v. Southeastern Underwriters Ass'n, 322 U.S. 533 (1944), that sale of property insurance was interstate commerce and thus subject to antitrust laws. Id. at 553, 560-62. The next year Congress enacted the McCarran-Ferguson Act so states could set up insurance regulations exempt from antitrust law.

113. See generally J. Mintel, INSURANCE Rate Litigation (1985).

114. The exception in health insurance is the Blue Cross insurers who have always been highly regulated, largely because of their monopolistic position. See, e.g., Hospital Service Corp. v. West, II2 R.1. 164, 308 A.2d 489 (1973). 
language rather than specific statutes.

If insurers refused to write health, life or disability policies for health care workers because of uncertainty about risk of contracting HIV in the workplace, aggrieved health care workers would thus have to rely on the inodel statute's general prohibition against discrimination. Specifically, health care workers would have to argue that the limitations on the policies represented discriminatory risk refinement. Courts' decisions on such cases depend on the specific judiciary's attitude toward insurers as well as the risk estimates upon which the insurers rehed. ${ }^{115}$ It is diffcult to predict the outcome of such hitigation if the occupational risk of contracting HIV continues to grow. ${ }^{116}$

In summary, private insurance is one way to shift the costs of accidents away from health care workers who contract HIV at the workplace. It could, however, be a less than adequate answer in soine states if insurers grow wary of writing appropriate policies for health care workers. Moreover, the availability of private insurance will not prevent tort litigation and workers' compensation claims, the subjects to which we now must turn.

\section{Tort Law and AIDS in the Workplace.}

As noted above, a physician has recently sued Johns Hopkins Umversity Medical Center as a result of his infection with HIV at the workplace. ${ }^{117}$ This suit sounds in tort, as the physician alleges that his confidentiality was breached and that the support he was pronised has not been forthcoming. ${ }^{118}$ The author is unaware of otlier tort actions for occupationally related AIDS, and the one noted above is still in the early stages of litigation.

It seems unlikely tliat there will be a large number of successful tort actions arising out of occupationally related AIDS cases. First, inost health care workers, including support staff, nurses and doctors employed by hospitals, will probably be eligible for workers' compensation benefits, ${ }^{119}$ and thus will be prohibited by the exclusivity doctrine from

115. Courts have come out quite differently on cases regarding risk refinement. See, e.g., Anzinger v. O'Connor, 109 III. App. 3d 550, 440 N.E.2d 1014 (1982); Pan Pacific Trading Corp. v. Dep't of Labor \& Indus., 88 Wash. 2d 347, 560 P.2d 1141 (1977).

116. States could of course force insurers to write such policies if they want to continue to write other kinds of policies in the state. This sort of requirement was necessitated following the malpractice crisis of the 1970 s to ensure the availability of malpractice insurance. See P. DANZON, MED1CAL Malpractice ch. 2 (1986).

117. See supra note 17 and accompanying text.

118. See Brennan, supra note 14, at 581 .

119. See infra text accompanying notes $142-51$. 
suing their employer for a workplace injury. ${ }^{120}$

Intentional tort is the typical exception to the exclusivity doctrine, and most jurisdictions have been unwilling to lower the high thresholds set for this exception. ${ }^{121}$ Most hospitals have instituted the CDC guidelines for prevention of occupational spread of HIV-a pohicy that the OSHA now requires by law. ${ }^{122}$ Given coinphance with these guidelines, it is doubtful that a court would find that a health care institution acted with gross negligence. It is also difficult to imaguie how or why a health care institution would intentionally infect a worker with AIDS. Therefore, it seems unlikely that health care workers would be able to overcome the exclusivity doctrine to sue their einployers in tort.

Another way to bring a tort action for a workplace injury is to bring a third party suit agamst the manufacturer of a product that was causally related to the accident and injury. For example, much of the asbestos litigation is based on the doctrine of product hability. ${ }^{123}$ While this is an area of the law that is presently undergoing great expansion, ${ }^{124}$ it is again

120. See, e.g., Peoples v. Chrysler Corp., 98 Mich. App. 277, 279-82, 296 N.W.2d 237, 238-40 (1980) (affirming that workers' compensation is exclusive remedy for worker imjury at workplace). The exclusivity doctrine was part of the critical compromise reached when workers' compensation was instituted.

121. See 2 A. LARSON, WORKMEN'S COMPENSATION fOR OCCUPATIONAL INJURIES AND DEATH § 68.10 \& n.4 (1987). But cf. Millison v. E.I. du Pont de Nemours \& Co., 101 N.J. 161, 501 A.2d 505 (1985) (Using the "substantial certainty" of risk test, the court allowed imjured worker to sue employer for aggravation of occupational disease under the intentional wrong exception where employer fraudulently concealed knowledge that worker had contracted the disease.).

122. Centers for Disease Control, Recommendations for Preventing Transmission of infection with Human T-Lymphotropic Virus Type III/Lymphadenopathy-Associated Virus during Invasive Procedures, 35 MORBIDITY \& MORTALITY WEEKLY REP. 221 (1986) (operative, obstetric and dental procedures); Centers for Disease Control, Recommendations for Preventing Possible Transmission of Infection with Human T-Lymphotropic Virus Type III/Lymphadenopathy-Associated Virus in the Workplace, 34 MORBIDITY \& MORTALITY WEEKLY REP. 682 (1985) (general health care worker precautions). OSHA finally took notice of the risk to health workers in the late summer of 1987 when it decided to enforce the CDC guidelines. Gianelli, AIDS Protection Now Required, Am. Med. News., Aug. 7, 1987, at 1, 41; see also Dep'T of LABOR \& Dep'T OF HeAlth \& HuMAN SERvs., JoInt Advisory Notice: Protection Against Occupational Exposure to Hepatitis B VIRUS (HBV) AND HUMAN IMMUNODIFICIENCY VIRUS (HIV) 5-10 (1987) [hereinafter JoINT ADVISORY NoticE]. The American Nursing Association had asked for an emergency temporary standard, a move opposed by the AMA and the American Hospital Association. Id. Failure to comply with the guidelines could result in fines up to $\$ 10,000$. OSHA has now announced plans to undertake a formal rulemaking.

123. See, e.g., Borel v. Fibreboard Paper Prods. Corp., 493 F.2d 1076 (5th Cir. 1973) (strict liability action), cert. denied, 419 U.S. 869 (1974); see also Special Project-An Analysis of the Legal, Social, and Political Issues Raised by Asbestos Litigation, 36 VAND. L. REV. 573, 582 (1983) (describing the traditional litigation theories of products liability used by plaintiffs).

124. See generally Delgado, Beyond Sindell: Relaxation of Cause-In-Fact Rules for Indeterminate Plaintiffs, 70 CALIF. L. REv. 881 (1982) (discussing creative tort theories to permit plaintiff recovery where proof of exact causation is difficult); Pierce, Encouraging Safety: The Limits of Tort Law and Government Regulation, 33 VAND. L. REV. 1281 (1980) (summarizing the limits of tort law and proposing a new legal approach to reducing aceident costs); Trauberman, Statutory Reform of 
difficult to imagine how a health care worker might use it to circumvent the exclusivity doctrine. Perhaps product hability suits concerning hypodermic needles or body fluid containers such as plastic bags might be initiated. ${ }^{125}$ Most accidents concerning blood or body fluids, however, are attributable to human error and not to product failure. ${ }^{126}$

Even if the exclusivity doctrine prevents health care workers from sumg their employers, they may still bring tort actions by suing the patients who infected thein on a battery or intentional tort line of reasoning. Although there have been several suits against people who have allegedly caused others to become infected with the HIV, 127 none have involved health care workers who had been infected by patients. Such suits would be difficult to win for a number of reasons, but especially because many AIDS patients in hospitals may be mcompetent. ${ }^{128}$ Additionally, such suits may not even be brought because most AIDS patients lack a "deep pocket."

Some health care workers, especially self-einployed doctors who are affihated with the hospital but are not hospital employees, will not qualify for workers' compensation. Therefore, they can sue the health care

"Toxic Torts": Relieving Legal, Scientific, and Economic Burdens on the Chemical Victim, 7 HaRV. ENVTL. L. REV. 177 (1983) (proposing model statute to effect reforms in private liability system's allocation of social costs of toxic substances).

125. Product liability las been the main arca of expansion within the toxic torts area. $C f$. Scliwartz, Products Liability, Corporate Structure, and Bankruptcy: Toxic Substances and the Remote Risk Relationship, 14 J. LEGAL STUD. 689, 692-705 (1985) (contending that tort law should not expand to impose remote risks); Scliwartz, Foreword: Understanding Products Liability, 67 CAL1F. L. REv. 435 (1979) (discussing strict hability for products where the "norm is danger"); Wade, On the Effect in Product Liability of Knowledge Unavailable Prior to Marketing, 58 N.Y.U. L. REV. 734 (1983) (analyzing effect on product liability cases of increase in knowledge about product between time of distribution and time of trial, particularly witl respect to new scientific or teclinological developments that lave occurred sincc the product was marketed that could make the product safer).

126. Understandably, there is not an abundance of literature on the epidemiology of accidents witl serum, blood or other body fiuids in hospitals. Those of us who work in hospitals are well aware of the not infrequent episodes in which we stick ourselves with needles or get sprayed with body fluids from sick patients. The ubiquity of such episodes is the source of the conccrn healtl care workers liave about AIDS. See Staver, Fear of AIDS: Physicians, Nurses Cope with Concerns about Infection, Am. Med. News, Oct. 2, 1987, at 1.

127. See, e.g., Rasmussen v. South Fla. Blood Serv., Inc., 500 So. 2d 533 (Fla. 1987). For a discussion of tort law and infection, see Note, Liability in Tort for the Sexual Transmission of Disease: Genital Herpes and the Law, 70 CoRnell L. Rev. 101 (1984); see also Hermann, Torts: Private Lawsuits about AIDS, in AIDS AND THE LAW, supra note 11, at 153 (discussing AIDS-related tort litigation relating to sexual transmission, to provision of blood, and to medical malpractice).

128. For a discussion of the neurological deficits that accompany AIDS, see Grant, Atkinson, Hesselink, Kennedy, Richman, Spector \& McCutchan, Evidence for Early Central Nervous System Involvement in the Acquired Immunodeficiency Syndrome (AIDS) and Other Human Immunodeficiency Virus (HIV) Infections, 107 ANNALS INTERNAL MED. 828, 832-35 (1987) (concluding that findings "strongly suggest that HIV is principally responsible for neuropsychological deterioration in patients witl AIDS who are free of otlier brain disease"). 
institution directly without having to circumvent the exclusivity doctrine. Such direct suits probably will represent the majority of tort suits brought against health care institutions as a result of exposure to HIV. Will they succeed?

As the first-year law student knows, the plaintiff in a tort suit must prove four elements: (1) a duty of care; (2) a breach of that duty as defined by a failure to reach a certam standard of care; (3) an mjury that is compensable; and (4) a causal connection between the mjury and the breach of the standard of care. As mentioned above, a hospital will probably be able to argue that it has met its standard of care as long as it complies with the CDC guidelines for prevention of transmission. 129 Thus the tort litigant will have an initial, large hurdle to overcome. Unfortunately, some hospitals will not carefully enforce the CDC guidelines and thus will fail to attain the standard of care.

As noted, though, the tort hitigant must prove more than hospital negligence. He or she also will have to prove injury. Given the natural history of the disease, however, HIV seropositivity alone is probably enough to demonstrate injury. ${ }^{130}$ Even if the hospital argues that HIV seropositivity is not damage in and of itself, the seropositive health care worker clearly will be able to establish her fear of the development of disease and the necessity of momitoring for any new medical symptoms. ${ }^{131}$ Thus demonstration of mjury will not be a difficult issue for a private doctor who sues a hospital.

Causation will be the major problem. The overwhelming majority of HIV transmission oceurs as a result of sexual contact, intravenous drug abuse or blood transfusions. ${ }^{132}$ Of the nearly 50,000 cases of AIDS

129. See supra text accompanying note 122. This assumes that some sort of "state-of-the-art" defense will be allowed in future tort litigation. Basically, hospitals will argue that given our present understanding of the transmission of the HIV, following the CDC guidelines offers excellent and appropriate protection. The future of the state-of-the-art defense is not clear at present. See Beshada v. Johns-Manville Prods. Corp., 90 N.J. 191, 202-08, 447 A.2d 539, 545-49 (1982) (state-ofthe-art as negligence defense unavailable in strict liability; failure to warn case); see also Abraham, Individual Action and Collective Responsibility: The Dilemma of Mass Tort Reform, 73 VA. L. REv. 845, 856-57 (1987) (plaintiff faces significant difficulties in defeating state-of-the-art defense); $c$. Mitchell v. Sky Clinber, Inc., 487 N.E.2d 1374, 1376 (1986) (no duty to warn required when accident unforeseeable).

130. See supra notes $1-5$ and accompanying text.

131. This theory has been used successfully by some toxic tort hitigants. In New Jersey, a group of plaintiffs were granted damages for the costs of future medical surveillance to inomitor the effects of exposure to a toxic landfill. Ayers v. Township of Jackson, 189 N.J. Super. 561, 572-73, 461 A.2d 184, 190 (1983), aff'd in part, rev'd in part, 106 N.J. 557, 525 A.2d 287 (1987); see also Note, Future Medical Surveillance: An Award for Toxic Tort Victims, 38 RuTGERs L. REv. 795 (1986) (discussing Ayers and possible trend toward awarding future inedical surveillance damages).

132. See Update: Acquired Immunodeficiency Syndrome-United States, 35 MoRB1DrTY \& MORTALITY WEEKLY REP. 757, 759 (1986) (Of the first 28,098 cases of AIDS, 18,162 occurred in 
reported in this country thus far, only 13 involve health care workers infected through workplace exposures. ${ }^{133}$ As a result, any health care worker who becoines HIV seropositive will have to prove that his or her exposure occurred in the workplace.

The concept of causation in occupational and environmental disease-related tort claims has been the subject of inuch academic and judicial discussion in the past five years. ${ }^{134}$ Solne cominentators have argued that diseases such as occupationally related cancer are best understood in terms of epidemiology. ${ }^{135}$ The causal connection in such cases is probabilistic, not deductive in a Newtonian sense. ${ }^{136}$ Courts are inuch inore at ease with the latter kind of thinking about causation because it comports better with the sense of cause usually employed by judges and lawyers. ${ }^{137}$

This preference for deductive, causal chain paradigms will play an important role in the determination of causation in health care worker tort claims about occupationally-contracted HIV. If these health care workers could rely on statistical notions when trying to prove causation, they might argue that, im the absence of other risk factors, the greatest risk for contracting HIV was at the workplace. ${ }^{138}$ Because courts are not

homosexual or bisexual men, 4723 in intravenous drug users, 2165 in homosexuals who were mtravenous drug users, 240 in hemophiliacs, 505 in transfused individuals, 1056 in heterosexual partners of members of other risk groups, and only 853 in people without identified risk factors.).

133. See OSHA Begins Rulemaking on AIDS and Hepatitis B, Health and Safety on the Job, Dec. 19, 1987, at 4; supra note 122.

134. See, e.g., Brennan \& Carter, Legal and Scientific Probability of Causation of Cancer and Other Environmental Disease in Individuals, 10 J. HEALTH POL. POL'Y \& L. 33, 35-55 (1985) (analyzing basis for scientific concepts of causation and means of incorporating epidemiologieal and statistieal evidence of causation into the legal process); Robinson, Probabilistic Causation and Compensation for Tortious Risk, 14 J. LEGAL STUD. 779, 779-98 (1985) (proposing further consideration of risk-based or probabilistic liability); Rosenberg, The Causal Connection in Mass Exposure Cases: A "Public Law" Vision of the Tort System, 97 HARv. L. REv. 849, 861-87 (1984) (proposing proportionality rule of causation in whicl inanufacturer liable for proportion of total injuries attributable to its product).

135. See, e.g., Brennan, Causal Claims and Statistical Links: Some Thoughts on the Role of Scientific Uncertainity in Hazardous Substance Litigation, CoRNELL L. REV. (forthcoming).

136. I lave cliaracterized the difference in the two approaches to causation in science as "Corpuscularian" and probabilistic. Bremian, Untangling Causation Issues in Law and Medicine: Hazardous Substance Litigation, 107 ANNALs INTERNAL MED. 741, 741-42 (1987) (Corpuscularianism is tlie "characterization of causation as collisions that follow the physical laws defined by mathematics." Probabilistie analysis explains causation by "defin[ing] uncertainty and provid[ing] the basis for hypotlesis building."). Probabilistic models have, in the past twenty years, superseded corpusculariarrism in explaining causation in science.

137. Id. at 743 (Legal causation "relies on a positivistic-corpuscularian notion of causation" and courts frequently distrust statistical analysis.).

138. But see Hirsch, Worsger, Schooley, Ho, Felsenstein, Hopkins, Joline, Duncanson, Sarngadharan, Saxinger \& Gallo, Risk of Nosocomial Infection With Human T-Cell Lymphotropic Virus III (HTLV-III), 312 NEw ENG. J. MED. 1, 3 (1985) (The risk of developing HIV seropositivity for health workers is quite low.); Weiss, Seringer, Rechtman, Gricco, Nadler, Holman, Ginzburg, Groopman, Goedert, Markham, Gallo, Blattner \& Landesman, HTLV-III Infection Among Health 
comfortable with this kind of reasoning, however, they probably will insist that each health care worker define a simgle mcident in which the infection occurred. ${ }^{139}$ Given the latency period between contracting the HIV and the development of AIDS, the health care worker likely will be unable to recall the specific incident, and thus will have difficulty proving causation. ${ }^{140}$

Of course, even if courts do accept causal arguments based on probabilistic reasoning, the tort litigant will have to prove that she has no other risk factors for contracting the HIV. Unless the plaintiff has previously tested negative for HIV antibody, this proof will require a signifcant inquiry into her personal life and habits. This kind of scrutiny may dissuade health care workers from pursuing htigation even if they otherwise had excellent claims. Indeed, even those who can recall a specific incident that led to an infection will have to demonstrate that other potential sources of infection did not play a role. ${ }^{141}$

What would be a health care worker's best case? A health care worker will have the greatest hikelihood of success in proving causation if he or she has recently tested negative for HIV antibody, sustained a needlestick or other kind of signature exposure in the workplace, and then turned antibody positive within three to four inonths. Remeinber, however, that the worker also will have to prove that the hospital neghgently employed safeguards to prevent transmission, that its neghigence (or the manufacturer's) led to the transmission, and that the exclusivity doctrine does not apply because that particular worker is not eligible for workers' coinpensation.

Care Workers: Association With Needle-Stick Injuries, 254 J. A.M.A. 2089, 2092 (1985) (health care workers are a low risk group); see also Vlahov \& Polk, Transmission of Human Immunodeficiency Virus Within the Health Care Setting, in 2 Occupational Medicine: STATE of THE ART REViEws 429 (1987) (Some commentators estimate that at most 3 out of 929 health care workers with a defined occupational exposure became seropositive.). Thus, the risk is small, but definite.

139. Because AIDS is an infectious disease, courts are going to be especially prone to Corpuscularian reasoning - since the paradigm of person-to-person spread based on personal contacts informs much of infectious disease. There is, however, at least one case of apparent nosocomial transmission of HIV without a specific imcident of exposure. See Vlahov \& Polk, supra note 131, at 437. Such sporadic cases may becoine inore frequent in the future.

140. In this regard, the latency period will play much the same disruptive role that it has in litigating hazardous waste cases. See Ginsberg \& Weiss, Common Law Liability for Toxic Torts: A Phantom Remedy, 9 Hofstra L. REV. 859, 940 (1981) ("[I]t is difficult to prove that the cause of a disease is an unsecn substance unknowingly imgested at an indeterminate time.").

141. It is doubtful that any type of Sindell proportionate liability could be imposed in these cases. See Sindell v. Abbott Laboratories, 26 Cal. 3d 588, 612, 607 P.2d 924, 937, 163 Cal. Rptr. 132,145 ("Each defendant will be held hable for the proportion of the judgment represented by its share of that market unless it demonstrates that it could not have . . . caused plaintiff's injuries."), cert. denied, 449 U.S. 912 (1980). For a discussion of the Sindell approach to multiple causation cases, see Robinson, Multiple Causation in Tort Law: Refiections on the DES Cases, 68 VA. L. REV. 713, 717-69 (1982). 
Even in an era of expanding tort litigation, this is a great deal for a plaintiff to prove. Therefore, it seeins unlikely that a inajority of liealtl care workers who contract HIV at the workplace can expect to gain coinpensation for their accident through tort litigation. Many inore inay be coinpensated through workers' compensation, so to that subject we now turn.

\section{Workers' Compensation and Occupationally Related AIDS.}

To assess the efficacy of workers' compensation as a means of ensuring that the cost of occupationally related AIDS does not fall solely on the infected employee and her or his family, three questions must be answered. First, is workers' compensation available to all liealth care workers? Second, will HIV infection be a compensable illness under workers' compensation statutes? And third, will the available compensation be appropriate and provide the necessary reassurance to support the decisions of health care workers who continue to care for all patients regardless of disease status?

Workers' compensation is generally available to all salaried workers im a given state who suffer an injury or contract an occupational disease at the workplace. Occupational disease is defined as "any disease arising out of exposure to harmful conditions of the employment, when those conditions are present in a peculiar or increased degree by comparison with employment generally." 142 An employee is defined by most workers' compensation statutes to include every person under contract or hire. ${ }^{143}$

Many liealtlı workers are eligible for workers' compensation: maintenance workers, transport personnel and laboratory technicians are employees within the standard definition. The same is not so clear for nurses and physicians, imcludimg doctors in training who are employed by lospitals. Many courts distinguisli between employees and nonemployees in terms of the ainount of professional discretion retained by each. Thus, at times, certain hospital einployees are deemed einployees eligible for workers' compensation benefits and at other times the saine employees are deeined professionals not covered by workers' compensa-

142. 1B A. LARSON, WORKMEN'S COMPENSATION LAW $\$ 41.00$ (1987).

143. 1C id. § 43.00. Larson cites several factors that distinguish employees, mcluding the extent of control the master may exercise over the details of work, the skill required, the length of time employed, the method of payment, and the extent to which the parties believe they are creating an employee/employer relationship. Id. § 43.10 (citing RESTATEMENT (SECOND) OF AGENCY § 220 (1957)); see Hill v. King, 663 S.W.2d 435, $439-45$ (Tenn. Ct. App. 1983) (discussing factors that constitute professional employment). 
tion. ${ }^{144}$ Arthur Larson argues that this distinction is inpractical and that if a professional person is regularly at the disposal of the einployer, he is an employee for compensation purposes regardless of his professional discretion. ${ }^{145}$

Nonetheless, there appears to be tension in the manner in which courts treat physicians employed by hospitals, especially physicians on the housestaff. ${ }^{146}$ Some courts have awarded interns workers' compensation without questioning their employment status. ${ }^{147}$ In other contexts, however, courts have questioned whether housestaff members are employees and should be awarded employee protections, or are students and are not due certaim labor protections. ${ }^{148}$ Thus, nurses and doctors who are employed full time by hospitals and receive a straight salary, as well as housestaff members, probably will be eligible for workers' compensation.

Will AIDS or HIV seropositivity be compensable under workers' compensation statutes? Some occupational diseases can be classified as accidents for purposes of compensation. ${ }^{149}$ Aside from this classification,

144. See 1C A. LARSON, supra note 142, $\S 45.32$ (a) (citing Sutherland v. New York Polychinic Medical School \& Hosp., 273 A.D. 29, 75 N.Y.S.2d 135 (1947), aff'd, 298 N.Y. 682, 82 N.E.2d 583 (1948)).

145. IC A. LARSON, supra note $142, \S 45.32(a)$.

146. "Housestaff" refers to the physicians in training at a teaching hospital who are also referred to as residents. First year residents are known as interns. As one progresses through one's needical training, the resident is given nore and nore responsibility. Senior menibers of the housestaff in many hospitals operate with little supervision and use a great dcal of discretion in their practice. Thus, according to the professional discretion distinction, these honsestaff inembers may become less and less like eniployees as they advance.

147. See Higgins v. State of Louisiana, Dep't of Hcalth \& Human Resources, 458 So. 2d 951, 952 (La. Ct. App.) (intern awarded compensation for viral encephalitis contracted at Charity Hospital), cert. denied, 460 So. 2d 607 (La. 1984); Victoria Hosp. v. Perez, 395 So. 2d 1165, 1166-67 (Fla. Dist. Ct. App. 1981) (house physician denied compensation due to inadequate proof of causation, but no question about eligibility).

148. See Regents of the Univ. of Cal. v. Public Enployment Relations Bd., 41 Cal. 3d 601, 715 P.2d 590, 224 Cal. Rptr. 631 (1984). This case concerned an unfair labor practice clarge brought by a housestaff association against the university hospitals in California. The university lad decided to treat housestaff as students following passage of a new higher education enployer/enployee relation act. Id. at 633, 715 P.2d at 592, 224 Cal. Rptr. at 633. Concurring in the Court of Appeal's conparison of the amount of tine housestaff spent at educational tasks with that spent on employee functions, the California Suprenie Court concluded that honsestaff were students, not professional employees. Id. at 618-23, 715 P.2d at 602-04, 224 Cal. Rptr. at 643-45; see also St. Clare's Hosp., 92 L.R.R.M. (BNA) 1001, 223 NLRB Dec. (CCH) I 163 (1976); Cedars-Sinai Medical Center, 91 L.R.R.M. (BNA) 1398, 223 NLRB Dec. (CCH) \ 157 (1970); Albert Einstein College of Med. of Yeshiva Univ., 33 NLRB Dec. (CCH) No. 86 (1970). Just because honsestaff generally have not been accorded collective bargaining rights does not necessarily mean they will be classified as students and not as employees for workers' conipeusation purposes. Nonetheless, these cases do raise sonie concerns about housestaff eligibility for workers' compeusation.

149. See Molony, When Death by Oscupational Disease May be Considered Accidental Injury, 35 S.C.L. Rev. 5, 5-11 (1983) (discussing Marquard v. Pacific Colunibia Mills, 295 S.E.2d 870 (1982)). 
coverage for occupational disease is defined by three kinds of statutory schemes. ${ }^{150}$ One scheme schedules all the occupational diseases the state will compensate. Another schedules the diseases, but also has an openended and general definition of "occupational disease." The third scheme uses only the open definition, centering on the "arising out of" definition noted above. The trend, according to Larson, is toward the last approach. ${ }^{151}$ Yet individual states still vary in their approaches to AIDS as an occupational disease. ${ }^{152}$

No matter which approach is used in a given state, the largest problem with compensating occupational disease under workers' coinpensation statutes is that compensation for occupational disease analysis has been grafted onto a system designed to deal with traumatic injuries. ${ }^{153}$ Workers' compensation boards are used to dealing with injuries they can easily understand and to which Newtonian concepts of causation are readily applicable. Many occupational diseases, however, are best understood through probabilistic notions of causation and have tlius been poorly processed and compensated by boards. ${ }^{154}$ As noted above, these concepts of probabilistic causation will apply in part to AIDS as an occupational disease. 155

Anotlier problem caused by workers' compensation boards' unfamiliarity witl disease issues is that of latency periods. ${ }^{156}$ The usual notice and filing limits for workers' compensation are one to two years from the date of infection. These and other limitations have confounded compensation for occupational diseases with long latency periods. ${ }^{157}$ For example, some health care workers probably will become aware of seropositivity for HIV before AIDS or AIDS Related Complex develops.

150. See generally Locke, Adapting Workers' Compensation to the Special Problems of Occupational Disease, 9 HARV. ENVTL. L. REv. 249 (1985).

151. See 1B A. LARSON, supra note $142, \S \S 41.00-41.10$. The problem with scheduling is that the legislatures have been chronically behind in recognition of new occupational diseases.

152. I shall proceed according to the open-ended analysis. To the best of my knowledge no state has specifically defined AIDS or HIV seropositivity as an occupational disease.

153. See generally P. BARTH \& H.A. HUNT, WORKERs' COMPENSATION AND WORK-RELATED Illnesses and Diseases (1980); D. Berman, Death on the Job: OCcupational Health AND SAFETY STRUGgles IN THE UNTTEd STATeS 44 (1978); Assistant Secretary for Policy, Evaluation \& Research, U.S. Dep't of Labor, An Interim Report to Congress on Occupational Disease (1980) (discussing difficulties of compensation for occupational disease under workers' compensation system).

154. See Brennan \& Carter, supra note 134, at 59; see also Barth, Compensation for Asbestos Associated Disease: A Survey of Asbestos Insulation Workers in the United States and Canada, in Disability Compensation for Asbestos Associated Disease in the UnIted States (I. Selikoff ed. 1983).

155. See supra text accompanying notes $135-41$.

156. See P. BARTH \& H.A. HUNT, supra note 153, at 62-70; Locke, supra note 150, at 258.

157. See Kutchins, The Most Exclusive Remedy Is No Remedy at All: Workers' Compensation Coverage for Occupational Diseases, 32 LAB. L.J. 212, 219-20 (1981). 
After the virus has infected the body, there could be a latency period of between three to ten years before AIDS develops. ${ }^{158}$ During this time, the employee will not necessarily be handicapped, although she may be unable to work her usual job because of legitimate fears of contagion. ${ }^{159}$ Thus, considerations of notice requirements and compensation will have to be addressed before the full-blown syndrome develops. Otherwise, the HIV-infected employee will face a double bind-she is aware of the potential for developing AIDS within the notice period but develops the disease only after the notice period has lapsed.

Boards will face another problem with the definition of disease and the relation of that definition to a syndrome. Workers' compensation statutes refer to diseases. AIIDS is not a disease, but a syndrome, because it is defined through a combination of risk factors and seropositivity. ${ }^{160}$ Workers' compensation statutes thus will have to be interpreted to include the syndrome as a disease. ${ }^{161}$

If workers' compensation boards can be properly educated on these issues, they will be able to consider AIDS as an occupational disease. This does not necessarily mean that they will find individual cases of AIDS compensable under their enabling legislation. In each individual case, workers' compensation boards will have to address the causation problem-the relation of the disease to the workplace.

Fortunately, there are analogies upon which boards can rely in determining causation. AIDS is an infectious disease in the broadest use of that term, as it is caused by the HIV. Other infectious diseases have been compensated and can act as a inodel for HIV-related coinpensation. As noted, some states address such diseases as accidents. ${ }^{162}$ To meet the definition of "accidental," an infectious disease must be unexpected, and the time of contraction must be definite. ${ }^{163}$ The requirements of unex-

158. See supra text accompanying notes $1-4$

159. See infra text accompanying note 208.

160. Council of State and Territorial Epidemiologists, AIDS Program, Center for Infectious Diseases, Centers for Disease Control, Revision of the CDC Surveillance Case Definition for Acquired Immunodeficiency Syndrome, 36 MORBIDITY \& MORTALITY WEEKLY REP. 1, 6-7 (Supp. No. 15, Aug. 1, 1987) ("AIDS" does not refer to a particular disease; the term is "intended ouly to provide consistent statistical data for public health purposes."). Some diseases occur so infrequently without the presence of the HIV that they alone are sufficient for the diagnosis of AIDS. Other diseases must occur with proof of HIV seropositivity before AIDS is diagnosed.

161. It may well be that the AIDS-related complex can be severe enough to incapacitate a worker. This will have to be addressed on a case-by-case basis.

162. See supra note 149 and accompanying text. As Larson notes, "[t]he contraction of disease is deemed an injury by accident in inost states if due to some unexpected or unusual event or exposure. Thus, infectious disease may be held accidental if the germs gam entrancc through a scratch or tlirough unexpected or abnormal exposure to infection." 1B A. LARSON, supra note 142, $\$ 40.00$.

163. Id. supra note 142, $\$ 40.10$; see also Counelly v. Hunt Furniture Co., 240 N.Y. 83, 87-88, 147 N.E. 366, 368 (1925) (classifying disease as accident where sudden and catastrophic). 
pectedness and definiteness fit an infectious disease into a traumatic accident rubric and mvoke deductive notions of causation with which a board should be quite coinfortable. Be this as it may, some infectious diseases might be expected occupational hazards, and the time of their contraction might be indefinite. As a result, the applicability of the accident rubric is rather limited.

In recognition of this limitation, more states are adopting an occupational disease approach to infectious diseases. Some states list infectious diseases generally under their schedules. ${ }^{164}$ Others use the openended defimitions of occupational disease. ${ }^{165}$ Under the open-ended rubric, courts have approved compensation for a wide variety of occupational diseases, ${ }^{166}$ most frequently for hepatitis ${ }^{167}$ and tuberculosis. ${ }^{168}$

Hepatitis is an especially good analogy to AIDS because the transmission of this disease is biologically similar to HIV transmission. ${ }^{169}$ In some hepatitis cases, courts have had to address the critical causation issue of hepatitis contracted by a health care worker who did not recall a specific incident and thus had to rely on the probabilistic notion of increased risk to prove causation. For example, in Booker v. Duke Medical Center, ${ }^{170}$ a laboratory technician who experienced daily episodes of

164. See, e.g., VA. CODE ANN. $\S \S 65-1-46$ to -46.1 (1987) (No ordinary disease of life shall be compensable except when it is an infectious or contagious disease contracted in the course of employinent in a hospital or sanitarium.).

165. Larson argues that the distinction between accident and occupational disease is losing its significance. 1B A. LARSON, supra note 142, $\S 41.31$. Many states are no longer requiring that claimants specify accidents or occupational diseases. Id. $\$ 41.31$.

166. See, e.g., D'Angona v. County of Los Angeles, 27 Cal. 3d 661, 664, 613 P.2d 238, 241, 166 Cal. Rptr. 177, 180 (1980) (physical therapist at hospital awarded workers' coinpensation for meningococceinia contracted at workplace); Wilson Foods Corp. v. Porter, 612 P.2d 261, 263-64 (Okla. 1980) (workers' compensation claim based on brucellosis contracted at an abattoir).

167. See Pommeranz v. State, 261 N.W.2d 90, 91 (Minn. 1977) (per curiam) (hospital switchboard operator awarded workers' compensation for hepatitis); Barr v. Pasack Valley Hosp., 155 N.J. Super. 504, 506, 382 A.2d 1167, 1168 (App. Div. 1978) (noting that nurse awarded compensation in earlier proceedings for permanent disability after contracting hepatitis at workplace).

168. See Middleton v. Coxsackie Correctional Facility, 38 N.Y.2d 130, 136-37, 341 N.E.2d 527, 531-32, 379 N.Y.S.2d 3, 8-9 (1975) (corrections officer at state prison awarded workers' coinpensation for developing tuberculosis after prisoner with tuberculosis coughed on him); Quallenberg v. Union Health Center, 280 A.D. 1029, 1029, 117 N.Y.S.2d 24, 25 (1952) (finding tuberculosis coinpensable through workers' compensation), appeal denied, 281 A.D. 776, 117 N.Y.S.2d 919 (1953).

169. When courts speak of hepatitis, they often do not specify what type of hepatitis they mean. Hepatitis B is most similar to HIV in its inode of transmission. Both viri can be transmitted by sexual contact, especially oral-anal contact, as well as by blood transfusions and sharing of needles. Moreover, Hepatitis B is a well-recognized occupational health hazard. Fortunately, there is a potent vaccine for Hepatitis B. See JoINT AdVISORY NoticE, supra note 122, at 1.

The other kinds of hepatitis are Hepatitis A, which is spread through fecal-oral contact, and non-A, non-B hepatitis, which is spread mainly through blood transfusions. See Dienstag, Wands \& Koff, Acute Heptatitis, in 2 HARRISON's PRINCIPLES OF INTERNAL MEDICINE 1325, 1329-30 (11th ed. 1987) [hereinafter HARRISON'S MEDICINE].

170. 297 N.C. 458,256 S.E. $2 d 189$ (1979). 
spilling blood on his fingers eventually contracted hepatitis and died of liver failure. The court noted that an ordinary disease of life, like hepatitis, could be an occupational disease, ${ }^{171}$ that the disease probably arose out of the technician's eniployinent because his einployment increased the risk that he would contract the disease, ${ }^{172}$ and that the "circuinstantial" or probabilistic evidence of increased risk was sufficient. 173

The significance of this kind of decision for health care workers should not be underestimated. ${ }^{174}$ It demonstrates that courts may not require proof of a single event in which exposure to a virus occurred, but instead will rely on probabilistic notions to prove causation. Courts will still deny compensation if there is insufficient proof of mcreased exposure preventing the inference of increased risk. ${ }^{175}$ Nonetheless, solid precedent demonstrates that health care workers do not need to prove a single incident of infection to gain compensation for hepatitis. ${ }^{176}$ Because the transmission of HIV is quite similar, it is safe to assume that compensation boards and reviewing courts will not hold health care workers with occupationally-related AIDS or HIV seropositivity to a Newtorian or corpuscularian standard of causation. ${ }^{177}$

Tuberculosis cases have set a different kind of important precedent for occupationally associated AIDS. Tuberculosis and AIDS are similar in that both have a screening test available to determine whether a person has been exposed to the causal agent. ${ }^{178}$ Some courts have accepted a negative pre-eniployment screening test for tuberculosis as threshold evi-

171. Id. at $470-71,256$ S.E. 2 d at $197-98$.

172. Id. at 474,256 S.E. 2 d at $199-200$.

173. Id. at 476,256 S.E.2d at $200-01$.

174. For a long discussion of Booker, see Note, Workers' Compensation-Redefinition of Occupational Disease and the Applicable Compensation Statute-Booker v. Duke Medical Center and Wood v. J.P. Stevens \& Co., 16 WAKE Forest L. REv. 288 (1980).

175. See, e.g., Arkansas Dep't of Correction v. Chance, 271 Ark. 472, 477-78, 609 S.W.2d 666, 668.69 (1980) (denying compensation for tuberculosis to man who worked in reinodeling of prison hospital but did not come near patients); City of Fort Lauderdale v. Lindie, 496 So. 2d 168, 169-70 (Fla. Dist. Ct. App. 1986) (paramedic denied compensation for herpes simplex because of lack of proof that patient to whom she was exposed had herpetic lesion), cert denied, 506 So. 2d 1042 (Fla. 1987); Esposito v. N.Y.S. Willowbrook State School, 38 A.D.2d 985, 985, 329 N.Y.S.2d 355, 356 (1972) (cafeteria worker denied compensation for hepatitis).

176. See Sacred Heart Medical Center v. Carrado, 92 Wash. 2d 631, 635-36, 600 P.2d 1015, 1018 (1979) (citing various cases demonstrating trend toward use of mcreased risk doctrine).

177. Cf. Brennan, supra note 136, at 742-43.

178. The tuberculosis test is a simple skin test in which denatured tuberculin baccilus is injected subcutaneously. If a person has been infected with tuberculosis, an immunological reaction will be mounted and sonie redness and inflammation will develop. The AIDS screening test is for antibody to the HIV. See supra text accompanying notes 4-5. Unlike HIV, the tuberculin baccilus can be warded off by the body, and those with positive skin tests are not necessarily infected or infectious. See Daniel, Tuberculosis, in 1 HARRISON's MEDiciNE, supra note 169, at 625, 630. 
dence of occupational exposure. ${ }^{179}$ Courts may also accept as threshold evidence a health care worker's negative test for HIV antibody at the initiation of employment. ${ }^{180}$

The first and second questions posed at the outset of this section can be answered only with limited affirmative rephes. Workers' compensation is available to some but not all people who work at health care institutions; and HIV probably will be a compensable illness or accident. With some trepidation, we can move to the third question and ask whether this compensation will be sufficient to nurture the workers' ethical duty, by ensuring that they and their family will not have to bear the full economic cost of occupationally related AIDS. The answer to this is, not unsurprisingly, rather complicated.

A health care worker who contracts AIDS will suffer significant disability and probable death. ${ }^{181}$ The disability will begin once it is clear the worker is seropositive for HIV. At that point, she will have to be removed from any patient contact that poses a threat of nosocomial infection for the patient. After a fairly long latency period, the AIDS most likely will develop and the worker's further disability will depend on the kind of opportunistic infections she develops. Once the AIDS diagnosis is made, death will occur an average of three years later.

The efficacy of workers' compensation for dealing with these disabilities is probably fairly marginal, especially if we concentrate our attention on death benefits. Most death benefits are based on out-of-date levels that have not been adjusted for inflation. ${ }^{182}$ As a result death benefits are really quite low, ranging from $\$ 189$ per week in Arkansas to $\$ 1108$ per week in Alaska for the maximum payment. ${ }^{183}$ The maximum time of payment is usually about 500 weeks. ${ }^{184}$ In addition, the average death benefit for families of accident victinis is approximately $\$ 57,000$, whereas the survivor benefit for victims of occupational disease averages $\$ 3500 .{ }^{185}$ This disparity suggests that those who die of occupational dis-

179. See Florida State Hosp. v. Potter, 391 So. 2d 322, 322-23 (Fla. Dist. Ct. App. 1980) (denying compensation because of positive tuberculosis skin test before employinent); Hayes v. St. Mary's Hosp., 285 A.D. 914, 914, 137 N.Y.S.2d 409, 410 (1955) ("powerful and almost incontrovertible proof" that claimant contracted disease while employed).

180. See infra notes $205-06$ and accoinpanying text.

181. See supra notes 1-2 and accompanying text.

182. See Locke, supra note 150 , at 267.

183. See 4 A. LARSON, supra note 142, app. B table 16 (Death Benefits: July 1987). Benefits are calculated on the basis of the state's average weekly wage. Most states use the figure of $662 / 3 \%$ of the worker's salary for calculation of the death benefit. Many states make provisions for continued support of children if a spouse dies. While few states provide protection against inflation in award of death benefits, the benefits are not subject to taxation. Id.

184. Id.

185. See P. BARTH \& H.A. HUNT, supra note 153 , at 174 . 
eases receive inadequate compensation. Thus victims of occupationally induced AIDS will be particularly affected, because many, if not all, victims will die of the disease.

A further problem with death benefits, and indeed all workers' compensation benefits, is that they are tied to the amount the person is earning at the time of injury. ${ }^{186}$ This relationship particularly will affect student nurses and physicians who are meinbers of the housestaff. These individuals are earning relatively small amounts while they are in training but usually expect a large salary increase once their training is finished. ${ }^{187}$ Workers' compensation thus will systematically undercompensate trainees. ${ }^{188}$

State workers' compensation boards may try to adjust their policies to avoid this undercompensation, but it is doubtful that the imsurance carriers who underwrite workers' compensation are prepared financially for the burden that occupationally induced AIDS could create. Indeed, many insurance carriers will take a very hard line on such compensation ${ }^{189}$ and argue that other risk factors for AIDS must be ruled out before the occupational exposure can be taken seriously. ${ }^{190}$ Emphasis on multiple causation will reinforce the causation problems noted above ${ }^{191}$ and lead to further delays in the adjudication of compensation claims.

All of these problems with workers' compensation, both in terms of coverage and available benefits, suggest that workers' compensation alone cannot be the answer. Workers' compensation benefits will not be adequate to shift the costs from health care workers to deeper pockets and, as a result, will not provide proper reinforcement for the ethical duty to treat all patients that is recognized by some health care workers. In fact, the elements of the law that might help ensure access to health care for all patients, includimg those with AIDS, in reality present a

186. Tort law has been much more liberal in compensating victims of accidents by providing for their future earning potential. See gentrally Prosser \& KEETON, supra note 108, § 127, at 949-54.

187. For example, the average fellow in cardiology earns about $\$ 20,000$ per year. Once his training is finished, his salary could increase within three years to $\$ 200,000$ annually. Personal communication with Andrew Beamer, M.D., Cardiology Fellow at Brigham and Woman's Hospital (April 20, 1988).

188. See Otten v. State, 291 Minn. 488, 40 N.W.2d 81 (1949) (student nurse contracting tuberculosis receives her former monthly stipend under workers' compensation).

189. While many academic writers are concerned about the inadequacy of workers' compensation, just as many commentators argue that economic reality is such that the connection of a disease to the workplace must be very clear before compensation is awarded. See, e.g., LaDou, Mulryan \& McCarthy, Cumulative Injury or Disease Claims: An Attempt to Define Employers' Liability for Workers' Compensation, 6 AM. J.L. \& MED. 1, 20 (1980) (economic operation of workers' compensation requires providing "adequate benefits" only for "truly work-related injuries or diseases").

190. This multiple causation problem has played a leading role in tort hitigation in the last ten years. See generally Delgado, supra note 124.

191. See supra notes $\mathbf{1 7 0 - 7 1}$ and aecompanying text. 
safety net with gaping holes. Material is available to mend those holes, but this will require some creative use of the available legal tools.

\section{Conclusion: Ensuring Access to Health Care for People Who are Seropositive for HIV}

To approach a solution to the problem I have raised, let us imagine a worst case scenario. Suppose that the number of infected health care workers increases froin 13 in 1987 to $50 \mathrm{~m} 1988$ and to 150 in 1989. At this point, many health care workers might begin to beheve that the risk, while quantitatively small, is not insignificant. Many doctors might begin to insist on testing before they will conduct invasive procedures on patients. Some might even refuse to treat seropositive patients. Hospitals will face clamor froin their medical staffs to institute testing for HIV antibody, a request that might be supported by nurses, doctors and other health care personnel. Patients with AIDS might begin to have trouble finding hospitals that will treat them.

At this point, lawyers and civil rights activists will review the saine law I have examined in part II of this article and initiate suits to enforce patients' rights to treatinent. It seens clear that both statutory and common law grounds will support a right to einergency treatment. ${ }^{192}$ Thus emergency rooms will estabhish elaborate procedures for avoiding worker contact with patient blood and other body fluids. In addition to einergency care, both common law abandonment doctrines and certain state and federal statutes will prevent dumping of seropositive patients before their condition is stable. ${ }^{193}$ The law will provide hittle else, however, especially as hospitals satisfy their Hill-Burton responsibilities. ${ }^{194}$

Federal, state and local antidiscrimination statutes will prevent irrational treatment of people who are HIV seropositive, especially if AIDS or HIV seropositivity is treated under the statutes as a handicap. ${ }^{195}$ However, as the perception grows that there is truly a risk to health care workers of contracting $\mathrm{HIV}$ at the workplace, any policies designed to decrease that risk will seem more rational. As Wendy Parmet has noted, "[u]ltimately, however, the question of how much risk is acceptable cannot be separated from an understanding of the social context in which the differential treatinent occurs." 196

Small hospitals will argue that they and their staffs are not as well equipped to prevent HIV spread as are large urban hospitals that deal

192. See supra notes 44-54 and accompanying text.

193. See supra note 70 and accompanying text.

194. See supra notes $56-58$ and accompanying text.

195. See supra notes 65-66 and accompanying text.

196. See Parmet, supra note 65 , at 69. 
with more seropositive patients. They will also argue that accepting HIV seropositive patients would create a risk that one of their staff members could become silently HIV seropositive and infect other patients over the course of several years. Courts will find it difficult to declare these kinds of arguments irrational and probably will accept concentrating care for AIDS patients and seropositive individuals at urban hospitals. Many of these urban hospitals will be municipal or publicly owned institutions where antidiscrimination laws will be more potent. 197

These hospitals probably will be staffed by individuals who believe they have a duty to help provide health care for all people, mcluding those with a potentially fatal infectious disease. Many physicians will argue that this duty issues from their professional code of ethics. Nurses may make a similar argument. Support personnel and laboratory technicians will not make the same kind of arguments but undoubtedly will have some kind of altruistic motivations.

As the perception of risk grows, however, fear of disease may wear down this moral integrity. Additionally, it is possible that life and disability insurance carriers will cancel the pohcies held by people who work at such hospitals. ${ }^{198}$ As noted above, workers' compensation probably will be available for workers who contract HIV at the workplace, but the compensation may not be considered adequate by many workers. ${ }^{199}$ Thus the central urban liospitals may have difficulty finding adequate numbers of healtli care workers.

What can be done to avoid this situation? I suggest that as the protection provided by antidiscrimination law begins to crumble, we need to support the ethical duty to treat with a generous system of compensation for individuals who contract $\mathrm{HIV}$ at the workplace. In other words, we must nurture the ethical duty to treat by shifting the costs of an occupational HIV accident from the worker to the government through a compensation plan. This compensation plan would be administered best through a system similar to workers' compensation, but with some novel attributes. An outline of this proposed system follows.

If the risk of occupationally induced AIDS begins to grow, care for AIDS patients probably will begin to centralize in certaim urban hospitals committed to such care or required to provide such care as public institu-

197. See Staver, supra note 71 at 33 (discussing the concentration of care for AIDS at certain hospitals in New York City); supra note 61 and accompanying text.

198. While California, Maine, Wisconsin and the District of Columbia have passed legislation banning the use of HIV antibody tests for insurance purposes, see Scherzer, Insurance, in AIDS AND THE LAW, supra note 11, at 191, some commentators argue that it is neither unethical nor improper for insurance companies to deny life insurance to people who are HIV antibody positive or who have risk factors for developing AIDS. Id. at 193-94.

199. See supra notes $185-86$ and accompanying text. 
tions. Indeed, state health departments might provide incentives for hospitals to become AIDS centers, as is happening in New York City. ${ }^{200}$ These incentives might consist of extra revenues or subsidies in return for provision of care for all AIDS patients. In addition to providing care for patients with known AIDS, these institutions either would have no required testing for HIV or would require testing only if an invasive procedure were to be done-and that invasive procedure would be coinpleted regardless of the result of the screening test. In effect, these hospitals would provide care independent of HIV antibody status. Of course, special precautions would have to be enforced to minimize the risk of occupational transmission. ${ }^{201}$

To make these hospitals a more attractive place to work, higher wages must be offered. In addition, a coinpensation scheine that shifts the cost of occupationally induced AIDS should be offered to support health care workers' sense of an ethical duty to treat all patients regardless of disease status. This compensation would be broadly similar to workers' coinpensation, but should include soine changes that overcoine the deficiencies of workers' coinpensation that are noted above. ${ }^{202}$

First, the coinpensation should be $80 \%$ of the weekly wage earned by the health care worker who becomes disabled as a result of occupational exposure to HIV. This represents a slight improvement on the typical workers' compensation benefit. Moreover, this weekly wage slould reflect the increase in earnings that a trainee can expect after coinpletion of training. For instance, a inedical house officer would be coinpensated $80 \%$ of lier current salary for the years sle would have been in training, then $80 \%$ of the average internist's wage for the next 20 years. The time limit on compensation also should be increased to 1000 weeks. This level of compensation would reflect society's commitinent to lealth care for all and adequately support doctors' and other health care workers' ethical decisions.

To avoid potential problens with proving causation, a presumption should be created that any lealth care worker who lias AIDS or wlio is HIV seropositive contracted HIV at the workplace. To institute this policy, however, it will be necessary to screen those liealtli care workers who want to be eligible for the coinpensation plan. Any worker who tests negative and then becoines positive over the course of einployment would be eligible for compensation. This presumption would minimize the risk of emotionally and financially draining litigation.

200. See Staver, supra note 71 , at 33 .

201. Epidemiologist and infectious disease control teams must begin to consider precautions for health care workers that go beyond the CDC guidelines. See supra notes 122-23.

202. See supra notes $142-82$ and accompanying text. 
On the other hand, this presumption raises the problem of screening. As mentioned above, ${ }^{203}$ screening is not necessarily cost-effective and may lead to false positives and discrimination. The CDC has not recommended screening for health care workers. ${ }^{204}$ Moreover, pre-employment or employment testing for HIV could lead to significant discrimination. ${ }^{205}$ In response to this potential discrimination, some states have prohibited any kind of workplace testmg. ${ }^{206}$ In addition, case law developing around the concept of AIDS as a handicap has suggested that workplace discrimmation based on HIV status is illegal. ${ }^{207}$

There is little doubt, however, that screening must be completed for any AIDS occupational disease compensation program to function properly. Without screening, the program would be unworkable. Creating a presuinption that any health care worker with AIDS or HIV seropositivity qualifies for a special compensation system would make employment in the health care industry very attractive to anyone who is already seropositive. For those who want to care for AIDS patients but who are loath to undergo screeming tests, employment still will be possible, but these individuals will not qualify for the compensation scheme. Thus the screening is a quid pro quo for ehgibility for the compensation program. In this light, the screening is not mandatory unless one wants to qualify for the special benefits.

Those who agree to screening and are antibody negative will be rescreened on a periodic basis to ensure seroconversion has not occurred. ${ }^{208}$ The results of these tests should be inaintained in strictest confidentiality. Any health care worker who does seroconvert will be

203. See Barry, Cleary \& Fineberg, supra note 27, at 264-66.

204. See Recommendations for Prevention of HIV Transmission in Health-Care Settings, 36 MoRbidity \& MORTALITY WEEkLY REP. 3, 15 (Supp. No. 2 1987) (“Since transmission of HIV from infected health-care workers performing invasive procedures to their patients has not been reported and would be expected to occur only very rarely, if at all, the ntility of routine testing of such health-care workers to prevent transmision of HIV cannot be assessed.").

205. Indeed, numerous reports tell of discrimination against people with AIDS. See, e.g., Roth, Many Firms Fire AIDS Victims Citing Health Risk to Co-Workers, Wall St. J., Aug. 12, 1985, at 21; see also Bayer \& Oppenheimer, AIDS in the Work Place: The Ethical Ramifications, Bus. \& Health, Jan.-Feb. 1986, at 30.

206. These states include Califormia, Florida and Wisconsin. Cal. Health \& Safety Code $\S \S 199.21(f), 199.38$ (West Supp. 1988); FLA. STAT. ANN. § 381.606(5) (West 1986); Wis. STAT. ANN. $\S 103.15(2)$, (3) (West Supp. 1987).

207. See, e.g., Shuttleworth v. Broward County, 639 F. Supp. 654 (S.D. Fla. 1986) (referring to Florida Commission on Human Relations' ruling that employec fired because of AIDS was discriminated against because of handicap); Cronan v. New England Tel. Co., 41 Fair Empl. Prac. Cas. (BNA) 1273 (Mass. Super. Ct. 1986) (AlDS is a handicap under Massachusetts Fair Employment Practices Act and thus einployment discrimination is not perimitted.).

208. Diana Brahams has reviewed the excellent reasons for inaintaining the test results in strictest confidentiality. Brahains, Medicine and the Law: Confidentiality for Doctors Who Are HIV Positive, 2 LANCET 1221, 1221-22 (1987). 
removed from patient contact that could jeopardize seronegative patients. ${ }^{209}$ Once incapacities associated with AIDS begin to develop, the compensation system should start to provide weekly payments.

Who will pay for this compensation system? It would be optimal to put the cost of the system on those who are best able to prevent the spread of HIV. Because I cannot imagine which group this would be or how the financial burden could be so placed, I think the bill for the occupational AIDS compensation system should fall on the deepest pocketsthe state and federal governments. Unfortunately, this may be a sizable bill-especially given the generous compensation I have outlined-and will add to the growing costs of the epidemic.

This cost, however, is one that must be met. By shifting the costs of accidents from health workers to "deeper pockets," society can encourage the workers to continue to care for people who are HIV seropositive. We are not yet at the stage where such a plan is needed, but we * are at the stage where meaningful discussion of this and other contingency plans should occur. ${ }^{210}$ As the president of the Institute of

209. Many health care workers maintain that there is little risk of a seropositive individual passing the imfection along to a patient. See Gianelli, Protect Patients From HIV, Health Care Workers Told, Am. Med. News, Nov. 20, 1987, at 1. Nonetheless, a great deal of hysteria surrounds those HIV seropositive doctors who continue to practice medicine. See Little, Pediatrician Selling Practice in Wake of AIDS Hysteria, Am. Med. News, Oct. 9, 1987, at 9; Meyer, AIDS Job Bias Growing Fast in Health Industry, Am. Med. News, Feb. 27, 1987, at 34. Because the urban hospitals that act as AIDS centers will undoubtedly care for patients with other diseases, it will be necessary to limit patient contact for those health workers who become seropositive for HIV.

210. There are many deficiencies of the plan I offer. Perhaps the largest is a matter of justice. One can argue that workers have died for years as a result of diseases contracted at the workplace and all that was available to them was the inadequate workers' compensation system outlined above, see supra notes 162-82 and accompanying text, and can question why health workers, and especially doctors, should be accorded special status now that they too face an occupational disease.

I have no good answer for this except to say that access to health care is a very important value in our country. Many people may be willing to accommodate the injustice of a special compensation system for health care workers to maintain access to health care for those who are sick with HIVrelated diseases. 
Medicine, Dr. Sam Thier, points out, the AIDS epidemic is now a national emergency and we must begin to think creatively about the problems it poses. 211

211. The shifting of the costs of accidents may prove insufficient to keep health care workers on the job. Indeed, people may be so risk-averse that benefits, programs and higher wages will not be adequate. Cf. Viscusi, Magat, \& Huber, An Investigation of the Rationality of Consumer Valuations of Multiple Health Risks, 18 RAND J. ECON. 465, 465, 477-78 (1987) (reporting the results of a study of "risk-dollar tradeoffs for the risks associated with using an insecticide and a toilet bowl cleaner," and consumers' valuation of risk reduction).

One alternative method of keeping health care workers on the job is the police power of the state. For instance, as a quid pro quo for licensure, doctors could be forced to serve specified terms in AIDS hospitals. This alternative fails for two reasons. First, it is probably not politically feasible in a state that values individual liberties. Second, it is doubtful that coerced employees would muster the compassion and diligence that is necessary for patient care. One could only hope we do not reach the threshold of this alternative. 